\title{
Thyroid Hormones Are Transport Substrates and Transcriptional Regulators of Organic Anion Transporting Polypeptide 2B1
}

\author{
Henriette E. Meyer zu Schwabedissen, Celio Ferreira, Anima M. Schaefer, Mouhssin Oufir, \\ Isabell Seibert, Matthias Hamburger, and Rommel G. Tirona
}

\begin{abstract}
Biopharmacy (H.E.M.z.S., C.F., A.M.S., I.S.), and Pharmaceutical Biology (M.O., M.H.), Department Pharmaceutical Sciences, University of Basel, Basel, Switzerland; and Departments of Physiology and Pharmacology and Medicine, University of Western Ontario, London, Ontario, Canada (A.M.S., R.G.T.)
\end{abstract}

Received December 18, 2017; accepted May 2, 2018

\begin{abstract}
Levothyroxine replacement therapy forms the cornerstone of hypothyroidism management. Variability in levothyroxine oral absorption may contribute to the well-recognized large interpatient differences in required dose. Moreover, levothyroxine-drug pharmacokinetic interactions are thought to be caused by altered oral bioavailability. Interestingly, little is known regarding the mechanisms contributing to levothyroxine absorption in the gastrointestinal tract. Here, we aimed to determine whether the intestinal drug uptake transporter organic anion transporting polypeptide 2B1 (OATP2B1) may be involved in facilitating intestinal absorption of thyroid hormones. We also explored whether thyroid hormones regulate OATP2B1 gene expression. In cultured Madin-Darby Canine Kidney II/OATP2B1 cells and in OATP2B1-transfected Caco-2 cells, thyroid hormones were found to inhibit OATP2B1-mediated uptake of estrone-3sulfate. Competitive counter-flow experiments evaluating the
\end{abstract}

influence on the cellular accumulation of estrone-3-sulfate in the steady state indicated that thyroid hormones were substrates of OATP2B1. Additional evidence that thyroid hormones were OATP2B1 substrates was provided by OATP2B1-dependent stimulation of thyroid hormone receptor activation in cell-based reporter assays. Bidirectional transport studies in intestinal Caco-2 cells showed net absorptive flux of thyroid hormones, which was attenuated by the presence of the OATP2B1 inhibitor, atorvastatin. In intestinal Caco-2 and LS180 cells, but not in liver Huh-7 or HepG2 cells, OATP2B1 expression was induced by treatment with thyroid hormones. Reporter gene assays revealed thyroid hormone receptor $\alpha$-mediated transactivation of the $S L C O 2 B 11 \mathrm{~b}$ and the SLCO2B1 1e promoters. We conclude that thyroid hormones are substrates and transcriptional regulators of OATP2B1. These insights provide a potential mechanistic basis for oral levothyroxine dose variability and drug interactions.

\section{Introduction}

Thyroid hormone (TH) homeostasis is essential for physiologic energy metabolism. Accordingly, alterations are linked to a variety of diseases. With a prevalence of about $4 \%$ to $5 \%$ in European and American populations, hypothyroidism (overt and subclinical) is among the most common diagnoses in endocrinology (Hollowell et al., 2002; Garmendia Madariaga et al., 2014). TH homeostasis is tightly regulated by multiple mechanisms, including those which control tissue uptake and cellular bioactivation. Thyroxine $\left(\mathrm{T}_{4}\right)$ is metabolized by intracellular iodothyronine deiodinases, which produce biologically active triiodothyronine $\left(\mathrm{T}_{3}\right)$ or inactive reverse triiodothyronine

The herein reported study is part of the master thesis of A.M.S. and part of the Ph.D. thesis of C.F.

The work was supported by the Swiss National Foundation [Grant 31003A 149603] (awarded to H.E.M.z.S.) and the Canadian Institutes of Health Research [Grant MOP-136909] (awarded to R.G.T.)

https://doi.org/10.1124/mol.117.111161.
$\left(\mathrm{rT}_{3}\right)$ (Köhrle, 2007). To signal transcription, $\mathrm{T}_{3}$ binds to intracellular TH receptors (TRs) (Mondal et al., 2016). The therapeutic management of hypothyroidism usually involves oral substitution with levothyroxine [(L-thyroxine) $\left.\mathrm{T}_{4}\right]$. However, oral absorption of L-thyroxine is highly variable and known to be affected by various factors including gastric $\mathrm{pH}$ or food-drug interactions (Ianiro et al., 2014). Furthermore, it is known that efficient L-thyroxine absorption from the intestinal lumen occurs in restricted segments of the gastrointestinal tract, namely, the duodenum and jejunum (Ianiro et al., 2014).

Intestinal solute transfer is mainly mediated by passive diffusion and active transport by membrane proteins. Several well-known drug-drug interactions result in reduced L-thyroxine bioavailability. For example, proton pump inhibitors alter the ionization status of L-thyroxine in the gut due to increased gastric $\mathrm{pH}$, while iron and calcium supplements may form nonabsorbable chelates or complexes with THs (Centanni et al., 2006). Interestingly, a population-based

ABBREVIATIONS: A, apical; ACN, acetonitrile; B, basal; DIO1, iodothyronine deiodinase 1; DMSO, dimethylsulfoxide; $\mathrm{E}_{1} \mathrm{~S}$, estrone-3-sulfate; FCS, fetal calf serum; KHB, Krebs-Henseleit buffer; L-thyroxine, levothyroxine; MDCKII, Madin-Darby canine kidney II; OATP, organic anion transporting polypeptide; $P_{\text {app }}$, apparent permeability; PBS, phosphate-buffered saline; PCR, polymerase chain reaction; P-gp, P-glycoprotein; QC, quality control; RPTEC, renal proximal tubular epithelial cell; $\mathrm{rT}_{3}$, reverse triiodothyronine; $\mathrm{RXR} \alpha$, retinoid $\mathrm{X}$ receptor alpha; $\mathrm{T}_{3}$, triiodothyronine; $\mathrm{T}_{4}$, thyroxine; $\mathrm{T}_{4} \mathrm{G}$, thyroxine 4-O- $\beta$ D glucuronide; TH, thyroid hormone; TR, thyroid hormone receptor; TR $\alpha$, thyroid hormone receptor alpha; TR $\beta$, thyroid hormone receptor beta; UHPLC-MS/MS, ultra-high-performance liquid chromatography-tandem mass spectrometry. 
retrospective study observed changes in thyroid-stimulating hormone levels, a marker for TH activity, to be associated with cotreatment with statins (Irving et al., 2015). Furthermore, an acute impact of ciprofloxacin or rifampin on intestinal absorption of L-thyroxine was shown, where ciprofloxacin significantly reduced $\mathrm{T}_{4}$ area under the plasma concentration-time curve by $39 \%$, while rifampin significantly increased $\mathrm{T}_{4}$ area under the plasma concentration-time curve by $25 \%$ (Goldberg et al., 2013). These later findings suggest that L-thyroxinedrug interactions may also result from mechanisms involving facilitated cellular entry or efflux (Riley et al., 2016).

With the discovery that MCT-8 (SLC16A2) genetic mutations cause Allan-Herndon-Dudley syndrome, a severe psychomotor retardation associated with $\mathrm{TH}$ dysregulation (Visser et al., 2011), it has become widely accepted that transporters are critically involved in the regulation of $\mathrm{TH}$ homeostasis and function (Bernal et al., 2015). Additional transporters have been reported to interact with $\mathrm{THs}$, including members of the organic anion transporting polypeptides (OATPs) (van der Deure et al., 2010). Within this protein family, OATP1C1 appears to be highly active and specific for TH transport, although it is only expressed at the blood-brain barrier and in the testis (Pizzagalli et al., 2002; Sugiyama et al., 2003). In addition, the hepatic transporters OATP1B1 and OATP1B3 have been reported to mediate cellular uptake of iodothyronine sulfates (van der Deure et al., 2008), thereby contributing to hepatic TH elimination. With regard to intestinal L-thyroxine absorption, the aforementioned OATPs appear to be of minor relevance due to their expression profile. In contrast, OATP1A2 was reported to be expressed in intestine (Glaeser et al., 2007) and to recognize THs as substrates (Fujiwara et al., 2001). However, intestinal OATP1A2 expression could not be subsequently confirmed; accordingly, the transporter is mainly considered important for blood-brain transfer (Lee et al., 2005; van der Deure et al., 2010).

A leading candidate for an intestinal $\mathrm{TH}$ transporter is OATP2B1 (SLCO2B1). This sodium-independent uptake transporter is expressed in enterocytes and assumed to significantly influence oral drug absorption (Tamai et al., 2000; Kullak-Ublick et al., 2001; Drozdzik et al., 2014). While most studies supported localization of OATP2B1 at the apical membrane of the enterocyte, its polarized cellular localization is a matter of debate since basolateral sorting has recently been proposed (Kobayashi et al., 2003; Keiser et al., 2017). Despite OATP2B1 being known to mediate cellular uptake of various exogenous compounds including statins (Koenen et al., 2011), it is less certain whether this transporter is also involved in intestinal absorption of $\mathrm{THs}$ since there are conflicting data. Interestingly, both studies reporting data on this used a similar experimental model involving Xenopus laevis oocytes expressing OATP2B1 (Kullak-Ublick et al., 2001; Leuthold et al., 2009). There are several transcription start site variants of OATP2B1 (Pomari et al., 2009), which are all regulated by their own distinct promoter (Fig. 8A, 1a to 1e). Of these five variants the OATP2B1 isoform $1 \mathrm{~B}$ (using exon $1 \mathrm{~b}$ as the transcription start site) encodes for the original fulllength protein and is the major form expressed in duodenum. All other variants that are transcriptionally controlled by different promoter regions encode for the same shortened protein lacking 22 amino acids at the $\mathrm{N}$-terminus. This short variant exhibits transport of estrone-3-sulfate $\left(\mathrm{E}_{1} \mathrm{~S}\right)$ and rosuvastatin comparable to the full-length OATP2B1 isoform
1B. For the OATP2B1-1E variant, liver-enriched expression and regulation by $\mathrm{HNF} 4 \alpha$ have recently been reported (Knauer et al., 2013). In this study, we investigated the functional and regulatory interplay of $\mathrm{TH}$ and the uptake transporter OATP2B1. Using cells overexpressing OATP2B1, we examined the impact of THs on cellular accumulation of the known OATP2B1-substrate $\mathrm{E}_{1} \mathrm{~S}$. Cellular accumulation studies were supplemented by counter-flow experiments and an assessment of the influence of OATP2B1 on the transactivation of $\mathrm{TH}$ receptor beta $(\mathrm{TR} \beta)$. Finally, we used the intestinal Caco-2 cell model to study transcellular TH transport as well as regulation of OATP2B1 expression.

\section{Materials and Methods}

Cell Culture. All cell lines were kept at $37^{\circ} \mathrm{C}$ in a humidified atmosphere supplemented with $5 \% \mathrm{CO}_{2}$. The cell lines Caco-2 (ATCC HTB37), HepG2 (ATCC HB-8065), HeLa (ATCC CCL-2), and MadinDarby canine kidney II [(MDCKII) ATCC CRL-2936] were originally obtained from American Tissue Culture Collection (Molsheim Cedex, France). Huh-7 cells (clone JCRB0403) were purchased from the Japanese Collection of Research Bioresources (http://cellbank. nibiohn.go.jp). Primary human renal proximal tubular epithelial cells (RPTEC) were purchased from Ruwag Life science (Bettlach, Switzerland). LS180 cells were commercially obtained from SigmaAldrich (Buchs, Switzerland). The OATP2B1 overexpressing cell line MDCKII-OATP2B1 was generated and characterized as described elsewhere (Grube et al., 2006). Dulbecco's modified Eagle's medium, supplemented with $10 \%$ fetal calf serum (FCS), and 1\% GlutaMAX (Thermo Fisher Scientific, Zug, Switzerland) were used as culture medium for the Caco-2, HeLa, HepG2, Huh-7, and MDCKII cells. In the case of MDCKII-OATP2B1 the medium was supplemented with $0.25 \mathrm{mg} / \mathrm{ml}$ Hygromycin B for continuous selection. Dulbecco's modified Eagle's medium supplemented with 1\% GlutaMAX, 10\% FCS, and $1 \%$ nonessential amino acids was the culture medium for the LS180 cells. The RPTECs were kept in optimized Clonetics REGM renal epithelial cell growth medium supplemented as recommended by the manufacturer (Lonza, Basel, Switzerland).

In Silico Scan for Potential Thyroid Hormone Receptor Binding Sites. The previously published sequences of the SLCO2B1 $1 \mathrm{~b}$ promoter and the $S L C O 2 B 1$ 1e promoter (Knauer et al., 2013) were screened for potential TR binding sites using the open-access program NUBIScan version 2.0 (www.nubiscan.unibas.ch). The underlying algorithm is a joining of weighted distribution matrices of nucleotide hexamer half-sites as published by Podvinec et al. (2002). The herein used search matrix was generated based on previously described specific DNA sequence binding pattern for TRs (Ayers et al., 2014).

Immunofluorescent Staining. Cells were seeded on cover slides at a density of 75,000 cells/well in 12-well plates. After reaching $90 \%$ confluence, cells were fixed with ice-cold methanol:aceton (1:2) for 15 minutes, permeabilized with $0.2 \%$ Tween 20/phosphate-buffered saline (PBS), and then incubated with 5\%-FCS-1\% bovine serum albumin/PBS before adding the anti-OATP2B1-antiserum (1:100) (Grube et al., 2006) for incubation over night at $4^{\circ} \mathrm{C}$. After several washes with PBS, the secondary antibody, anti-rabbit Alexa Fluor 488 (Life Technologies distributed by Thermo Fisher Scientific, Zug, Switzerland), was added for 1 hour. Prior to mounting the cells with Roti-Mount FluorCare containing 4',6-diamidino-2-phenylindole (DAPI) for nuclei staining, the cells were washed with PBS. Staining was detected using the Leica DMi8 Microscope (Leica Microsystems, Heerbrugg, Switzerland).

Quantitative Real-Time Polymerase Chain Reaction (PCR) Analysis. Caco-2, LS180, Huh-7, and HepG2 cells were cultured at

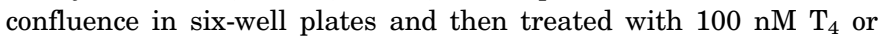
$100 \mathrm{nM} \mathrm{T}_{3}$. After 48 hours of treatment, total RNA was extracted using TRIzol reagent (Thermo Fisher Scientific). The quality of the RNA was determined using Agilent Bioanalyzer 2100 (Agilent, Santa Clara, CA) 
and the concentration was measured by spectrophotometry (GE Nanovue Plus; GE Healthcare Life Sciences, Baie d'Urge, QC, Canada). cDNA was synthesized using the Applied Biosystems Multiscribe Reverse Transcriptase (distributed by LuBioScience, Lucern, Switzerland). Human tissue RNAs were purchased from AMS Biotechnology (Bioggio-Lugano, Switzerland) or isolated from RPTEC, Caco-2, or Huh7 using pegGold RNA Pure (Axon Laboratory, Baden-Dättwil, Switzerland) following the manufacturer's protocol. The Life Technologies High-Capacity cDNA Reverse Transcription Kit (distributed by LuBioScience) was used for reverse transcription. The amount of mRNA was quantified using the ViiA7 Real-Time PCR System and commercially available TaqMan gene expression assays (LuBioScience) for TR beta [(TR $\beta), H s 00230861]$, TR alpha [(TR $\alpha)$, Hs00268470_m1], iodothyronine deiodinase 1 [(DIO1), Hs00174944_m1], and 18S ribosomal RNA [(18S rRNA), 4319413E]. The amount of SLCO2B1 isoforms $1 \mathrm{~B}$ and $1 \mathrm{E}$ was analyzed using SYBR Green PCR Master Mix (LuBioScience) and the following primers: SLCO2B1_1B_forward 5'-GGCTGGAGCTCACTGCAC-3', SLCO2B1_1E_forward 5'-TGGGATTGAAGCTTCAGGGAG-3', and SLCO2B1_1B/1E_reverse 5'-CACTGTGGAAATGGAGCTC-3', as previously reported by Knauer et al. (2013). In the cells, DIO1 and ABCB1 were quantified using the primers DIO1_forward 5'-TTCAGCACCAGTGGCCTATT-3', DIO1_reverse 5'-ACGACTGAGCTAGGGGGTCT-3', P-glycoprotein (P-gp)_forward 5'-GTCCCAGGAG-CCCATCCT-3', and P-gp_reverse 5'-CCCGGGTGTTGTCTCCAT-3' . Data were analyzed by the $\Delta \Delta \mathrm{CT}$ method, where the CT values of the gene of interest were normalized to that of $18 \mathrm{~S}$ rRNA detected in the same sample $(\Delta \mathrm{CT})$. The $\Delta \mathrm{CT}$ values of each sample were referred to the mean $\Delta \mathrm{CT}$ value of the indicated control $(\Delta \Delta \mathrm{CT})$.

Transport Studies Using MDCKII-OATP2B1 Cells. For inhibition studies and competitive counter-flow experiments, MDCKII or MDCKII-OATP2B1 cells were seeded at a density of 50,000 cells/well in 24-well plates. One day after seeding, cells were stimulated with $2.5 \mathrm{mM}$ sodium-butyrate for 24 hours. For inhibition studies, cells were washed with prewarmed PBS prior to the 5-minute incubation with $\mathrm{E}_{1} \mathrm{~S}$ diluted in incubation buffer $(142 \mathrm{mM} \mathrm{NaCl}, 5 \mathrm{mM}$ $\mathrm{KCl}, 1 \mathrm{mM} \mathrm{KH} \mathrm{PO}_{4}, 1.5 \mathrm{mM} \mathrm{CaCl}_{2}, 1.2 \mathrm{mM} \mathrm{MgSO}_{4}, 5 \mathrm{mM}$ glucose, and $12.5 \mathrm{mM}$ HEPES). $\mathrm{E}_{1} \mathrm{~S}$ was used at a concentration of $0.1 \mu \mathrm{M}$ containing $100,000 \mathrm{dpm} /$ well $\left[{ }^{3} \mathrm{H}\right]-\mathrm{E}_{1} \mathrm{~S}$ (Hartmann Analytic, Braunschweig, Germany), supplemented with the respective concentration of the tested inhibitor, namely, $\mathrm{T}_{4}, \mathrm{~T}_{3}, \mathrm{rT}_{3}$, and thyroxine 4-O- $\beta$-D-glucuronide $\left(\mathrm{T}_{4} \mathrm{G}\right)$ (all obtained from SigmaAldrich). Atorvastatin [1 or $10 \mu \mathrm{M}]$ was used as the control. After washing the cells three times with ice-cold PBS, cells were lysed in $200 \mu \mathrm{l} 10 \%$ SDS-5 mM EDTA. Cellular accumulation of the radiolabeled substrate was determined after diluting the cell lysate in $2 \mathrm{ml}$ of scintillation cocktail (Rotiszint eco plus; Carl Roth AG, Arlesheim, Switzerland) and measured using a liquid scintillation $\beta$-counter (Tricarb 2900 TR; TOPLAB, Rickenbach, Switzerland). Competitive counter-flow experiments were performed as described by Harper and Wright (2013). One day after seeding, the cells were washed once with prewarmed PBS and exposed to Krebs-Henseleit buffer [(KHB); $118 \mathrm{mM} \mathrm{NaCl}, 25 \mathrm{mM} \mathrm{NaHCO} 3,1.2 \mathrm{mM} \mathrm{KH}_{2} \mathrm{PO}_{4} ; 2.5 \mathrm{mM} \mathrm{CaCl}_{2}$, $1.2 \mathrm{mM} \mathrm{MgSO}_{4}, 11 \mathrm{mM}$ glucose, $\left.4.7 \mathrm{mM} \mathrm{KCl}, \mathrm{pH} 5.5\right]$ containing $\left[{ }^{3} \mathrm{H}\right]$ $\mathrm{E}_{1} \mathrm{~S}(6.06 \mathrm{nM} /$ well with $100,000 \mathrm{dpm} /$ well $)$ for 30 minutes to equilibrate. After reaching steady-state conditions, the supernatant was removed and replaced by KHB containing $\left[{ }^{3} \mathrm{H}\right]-\mathrm{E}_{1} \mathrm{~S}$ supplemented with the test compounds, namely, $\mathrm{E}_{1} \mathrm{~S}(50 \mu \mathrm{M})$, atorvastatin $(30 \mu \mathrm{M})$, camptothecin $(1 \mathrm{mM}), \mathrm{T}_{4}(25 \mu \mathrm{M}), \mathrm{T}_{3}(10 \mu \mathrm{M}), \mathrm{rT}_{3}(1 \mathrm{mM})$, or $\mathrm{T}_{4} \mathrm{G}$ $(400 \mu \mathrm{M})$. After 1-minute incubation the cells were washed with icecold PBS and the amount of radiolabel in the lysed cells was determined as described previously.

Transport Studies Using Transiently Transfected Caco-2 Cells. Caco-2 cells were seeded at a density of 75,000 cells/well in 24 -well plates. One day after seeding the cells were transfected with $500 \mathrm{ng} /$ well pEF6-control or OATP2B1-pEF6 using $2 \mu \mathrm{l} / \mu \mathrm{g}$ DNA jetPRIME transfection reagent (Polyplus transfection; Chemie Brunschwig AG, Basel, Switzerland), and the next day transport experiments were conducted as previously described in detail.
Cell-Based Reporter Gene Assays. To test the influence of the uptake transporter on the intracellular function of $\mathrm{T}_{3}$ and $\mathrm{T}_{4}$, MDCKII or MDCKII-OATP2B1 cells were transfected with a reporter gene construct containing the firefly luciferase gene under the control of the $5^{\prime}$ untranslated region of the iodothyronine deiodinase 1 gene (DIO1-pGL3basic) and pRL-TK encoding for Renilla luciferase as the transfection control. For cell-based reporter gene assays testing the transactivation of the SLCO2B1 1e and SLCO2B1 $1 \mathrm{~b}$ promoters, the respective reporter gene constructs in pGL3basic (Knauer et al., 2013) were transfected into HeLa cells. In addition to the reporter gene constructs, the cells were transfected with eukaryotic expression vectors (pEF6-V5/HIS; Invitrogen distributed by Thermo Fisher Scientific) encoding for the nuclear receptor TR $\beta$, $\operatorname{TR} \alpha$, and/or its heterodimerization partner retinoid X receptor alpha (RXR $\alpha$ ); in total, $25 \mathrm{ng}$ pRL-TK, $250 \mathrm{ng}$ of TR $\beta$-pEF6, TR $\alpha$-pEF6, and/or RXR $\alpha$-pEF6 and/or pEF6 as control, and $250 \mathrm{ng}$ of the pGL3basic plasmid were transfected in each well. MDCKII or MDCKII-OATP2B1 cells were seeded at a density of 40,000 cells/well in a 24 -well plate, and after 24 hours the cells were transfected using $1.5 \mu \mathrm{l} / \mu \mathrm{g}$ DNA of the jetPRIME transfection reagent (Polyplus transfection). HeLa cells were seeded at a density of 50,000 cells/well in 24-well plates, and were transfected using $2.5 \mu \mathrm{l} / \mu \mathrm{g}$ DNA of the jetPRIME transfection reagent (Polyplus transfection). The next day, the cells were treated for 24 hours with $10 \mu \mathrm{M} \mathrm{T}$ or $10 \mu \mathrm{M} \mathrm{T}_{4}$. Subsequently, the cells were lysed in $100 \mu \mathrm{l}$ passive lysis buffer, and then the firefly and Renilla luciferase activities were assessed in $20 \mu \mathrm{l}$ of the lysate using the Dual-Luciferase Reporter Assay System (Promega, Duebendorf, Switzerland) and the infinite 200 Pro (Tecan, Maennedorf, Switzerland) according to the manufacturers' instructions. Activity of firefly luciferase was normalized to that of Renilla.

Western Blot Analysis. For determination of protein content, cells were lysed in $5 \mathrm{mM}$ Tris- $\mathrm{HCl}$ ( $\mathrm{pH}$ 7.4) supplemented with protease inhibitors (diluted 1:100; Protease Inhibitors Cocktail; Sigma-Aldrich). After three cycles of freezing in liquid nitrogen and thawing in a $37^{\circ} \mathrm{C}$ water bath, the cell lysate of MDCKII cells was centrifuged at $100,000 \mathrm{~g}$ ( 30 minutes at $4^{\circ} \mathrm{C}$ ) for crude membrane enrichment. The resulting pellet was suspended in $5 \mathrm{mM}$ Tris-HCl supplemented with protease inhibitors. For cultured Caco-2 cells, we applied the total cell lysate to immunoblotting. After adding $5 \mathrm{x}$ Laemmli buffer, the samples were heated for 30 minutes to $65^{\circ} \mathrm{C}$ prior to separation by $10 \%$ SDS-PAGE. The separated proteins were electrotransferred to a nitrocellulose membrane using a TANK blotting system (Bio-Rad, Cressier, Switzerland). Prior to incubation with the respective antibodies, anti-OATP2B1 rabbit polyclonal (Grube et al., 2006) or goat polyclonal anti- $\beta$-actin (sc-1616; Labforce, Muttenz, Switzerland), the membranes were blocked with 5\% FCS in Tris-buffered saline containing $0.1 \%$ Tween 20 for at least an hour at room temperature. After several washing steps with Tris-buffered saline containing $0.1 \%$ Tween 20 the membranes were incubated with the respective horseradish peroxidase-labeled secondary antibody (dilution to 1:2000; Bio-Rad). Immobilized secondary antibody was visualized and digitalized using Western ECL Substrate (Thermo Fisher Scientific) and the ChemiDoc MP System (Bio-Rad), respectively. Analysis was performed using the Image Laboratory software (version 4.1; Bio-Rad).

Transwell Transport of Thyroid Hormones. Transepithelial solute flux studies were performed as previously published by Hubatsch et al. (2007). Briefly, Caco-2 cells were seeded at a density of $3 \times 10^{5}$ cells/well onto polycarbonate membranes with $0.4 \mu \mathrm{m}$ pore size inserted in 12-well plates (Chemie Brunschwig AG). Caco-2 cells were cultivated for at least 14 days with medium change every second day, and until reaching a transepithelial electrical resistance value of at least $200 \Omega / \mathrm{cm}$. Integrity of the monolayer was tested after assessment of transport using $0.1 \mathrm{mg} / \mathrm{ml}$ lucifer yellow (SigmaAldrich). Transport experiments were performed using KHB. In detail, after washing the cells with PBS, Caco-2 cells were preequilibrated for 20 minutes at $37^{\circ} \mathrm{C}$ with $\mathrm{KHB}$. The apical compartment was filled with $0.5 \mathrm{ml}$ of $\mathrm{KHB}$, the basolateral compartment was 
TABLE 1

Optimized tandem mass spectrometry parameters in electrospray ionization positive mode for analytes and the corresponding internal standards

\begin{tabular}{|c|c|c|c|}
\hline \multirow{2}{*}{ Analyte I.S. } & \multirow{2}{*}{ MRM Transition } & Cone Voltage & \multirow{2}{*}{$\begin{array}{c}\begin{array}{c}\text { Collision } \\
\text { Energy }\end{array} \\
e V\end{array}$} \\
\hline & & $V$ & \\
\hline $\mathrm{T}_{3}$ & $651.6 \rightarrow 197.1$ & 55 & 80 \\
\hline I.S. ${ }^{13} \mathrm{C}_{6} \mathrm{~T}_{3}$ & $658.0 \rightarrow 612.0$ & 50 & 32 \\
\hline $\mathrm{T}_{4}$ & $777.3 \rightarrow 633.8$ & 60 & 42 \\
\hline I.S. ${ }^{13} \mathrm{C}_{6} \mathrm{~T}_{4}$ & $783.4 \rightarrow 737.7$ & 55 & 32 \\
\hline
\end{tabular}

I.S., internal standard; MRM, multiple reaction monitoring.

filled with $1.5 \mathrm{ml}$ of $\mathrm{KHB}$, and $10 \mu \mathrm{M} \mathrm{T}_{3}$ or $10 \mu \mathrm{M} \mathrm{T}_{4}$ was applied to the donor compartment. Inhibition of OATP2B1 was achieved by application of $10 \mu \mathrm{M}$ atorvastatin (USP, Basel, Switzerland) on the apical site. Accumulation in the acceptor compartment and remaining amount in the donor compartment was quantified in $200 \mu \mathrm{l}$ aliquots taken at 30 minutes and replaced with KHB buffer. At 60 minutes a second aliquot was taken. Both apical and basolateral KHB samples were stored in glass vials (to avoid long-term nonspecific adsorption) below $-65^{\circ} \mathrm{C}$ prior to quantification by ultra-high-performance liquid chromatography-tandem mass spectrometry (UHPLC-MS/MS) as described subsequently. The apparent permeability $\left(P_{\text {app }}\right)$ coefficient was calculated as previously described (Hubatsch et al., 2007). The determined unidirectional apparent permeability coefficients in the apical (A)-to-basal (B) or B-to-A direction were used to calculate the uptake ratio. In accordance with the commonly used efflux ratio, the uptake ratio was calculated as follows:

$$
\text { uptake }- \text { ratio }=\frac{P_{\text {app }}(\text { A to } \mathrm{B})}{P_{\text {app }}(\text { B to } \mathrm{A})}
$$

Triiodothyronine and Thyroxine Quantification by UHPLCMS/MS. For the quantification of $\mathrm{T}_{3}$ and $\mathrm{T}_{4}$ in the range of 30 $3000 \mathrm{ng} / \mathrm{ml}$, specific UHPLC-MS/MS methods were developed. For both $\mathrm{T}_{3}$ and $\mathrm{T}_{4}$, seven calibration standards (calibrators) and three levels of quality controls (QCs) in $\mathrm{KHB}$ at low (QC $90 \mathrm{ng} / \mathrm{ml}$ ), medium (QC $1500 \mathrm{ng} / \mathrm{ml}$ ), and high (QC $2400 \mathrm{ng} / \mathrm{ml}$ ) concentrations were prepared by serial dilution of the respective working solution $(100 \mu \mathrm{g} / \mathrm{ml}$ in methanol for both $\mathrm{T}_{3}$ and T4). The first concentration ( $30 \mathrm{ng} / \mathrm{ml}$ ) of the calibrators was defined as the lower limit of quantification, and the highest concentration $(3000 \mathrm{ng} / \mathrm{ml})$ was defined as the upper limit of quantification. Calibrators and $\mathrm{QCs}$ were stored in aliquots in polypropylene tubes below $-65^{\circ} \mathrm{C}$ until analysis. ${ }^{13} \mathrm{C}_{6}-\mathrm{T}_{3}$ and ${ }^{13} \mathrm{C}_{6}-\mathrm{T}_{4}$ (dissolved to $1000 \mathrm{ng} / \mathrm{ml}$ in methanol; Sigma-Aldrich) were used as internal standards for $\mathrm{T}_{3}$ and $\mathrm{T}_{4}$, respectively. To $20 \mu \mathrm{l}$ of the KHB samples from the Transwell studies, $100 \mu \mathrm{l}$ of each internal standard, $200 \mu \mathrm{l}$ bovine serum albumin solution ( $60 \mathrm{~g} / \mathrm{l})$, and $700 \mu \mathrm{l}$ of ice-cold acetonitrile (ACN) were added. The mixture was briefly vortexed, mixed for 10 minutes at $1400 \mathrm{rpm}$ and room temperature, and then centrifuged for 20 minutes at $13,200 \mathrm{rpm}$ and $10^{\circ} \mathrm{C}$. The supernatant was transferred into a 96-deep-well plate, dried under heated nitrogen gas flow $\left(30-50^{\circ} \mathrm{C}\right.$; Evaporex EVX-96; Apricot Designs, Monovia, CA), and reconstituted with $200 \mu \mathrm{l}$ of injection solvent (35\% eluent A and $65 \%$ eluent B; eluent A: $0.1 \%$ formic acid in water; eluent B: $0.1 \%$ formic acid in ACN) under shaking (1500 rpm) for 45 minutes at room temperature. Subsequently, each sample was transferred into a $300 \mu \mathrm{l}$ glass insert of a high-performance liquid chromatography vial before injection into the UHPLC-MS/MS system in full-loop mode $(5 \mu \mathrm{l})$. Quantification was performed using an UPLC HSS T3 column on an Acquity UPLC system consisting of a binary pump, an autosampler set at $10^{\circ} \mathrm{C}$, and a column heater set at $45^{\circ} \mathrm{C}$, which was coupled to an Acquity TQD tandem mass spectrometer (all obtained from Waters Corp., Milford, MA). The mobile phase consisted of eluents A and B. Chromatographic separation was performed at a flow rate of $0.5 \mathrm{ml} / \mathrm{min}$ with the following gradient: 0 to 1 minute, B $5 \%$; $1-5$ minutes, B $5 \%-100 \%$; 5 to 6 minutes, B 100\%; 6-6.01 minutes, B $100 \%-5 \%$; $6.01-7$ minutes, B 5\%.

B

A
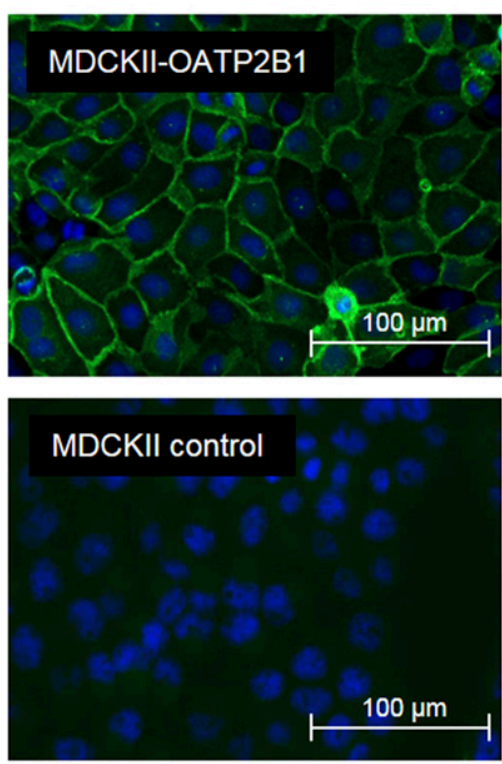

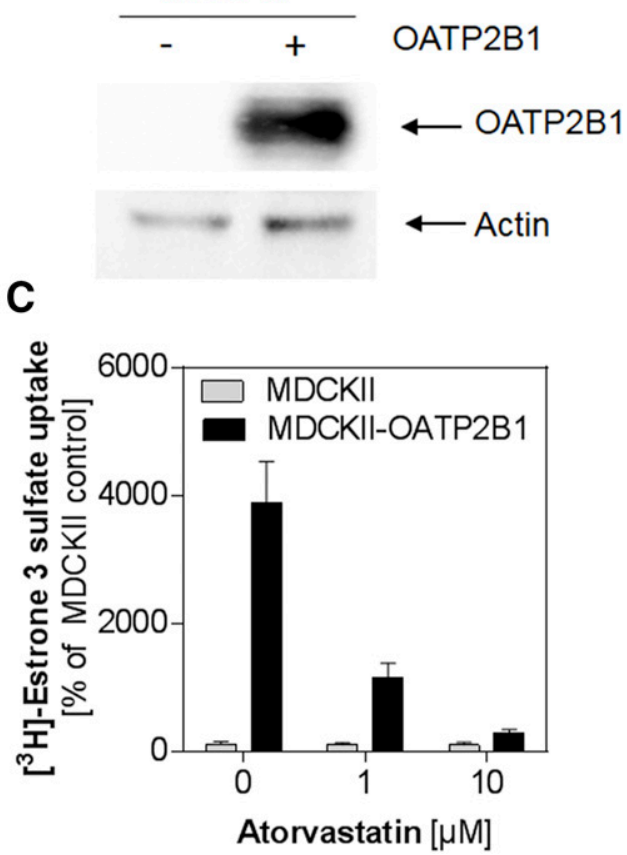

Fig. 1. Validation of OATP2B1 expression and function in stably transfected MDCKII cells. Immunofluorescent staining of MDCKII-OATP2B1 and MDCKII cells revealed localization of the transporter in the basolateral membrane of polarized MDCKII cells overexpressing the transporter. No signal was observed in MDCKII cells (A). Immunoblot analysis verified high expression when comparing MDCKII and MDCKII-OATP2B1 cells, as shown in the representative blot $(B)$. Uptake of $\left[{ }^{3} \mathrm{H}\right]-\mathrm{E}_{1} \mathrm{~S}$ was significantly enhanced in the presence of the transporter, while it was reduced by co-incubation with atorvastatin (C). 
A

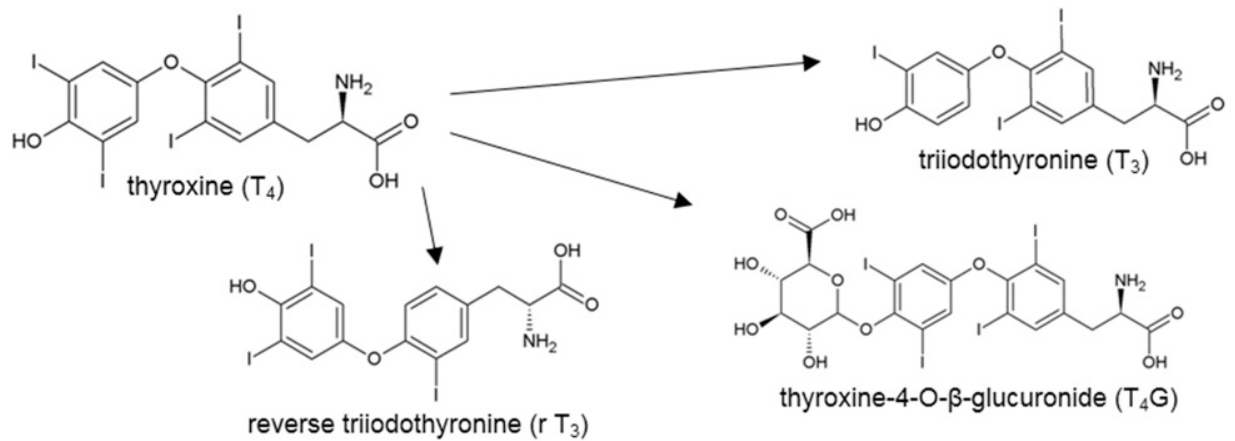

B

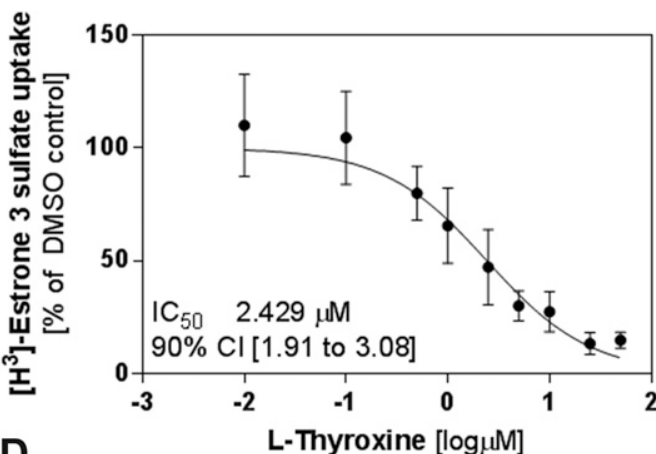

D

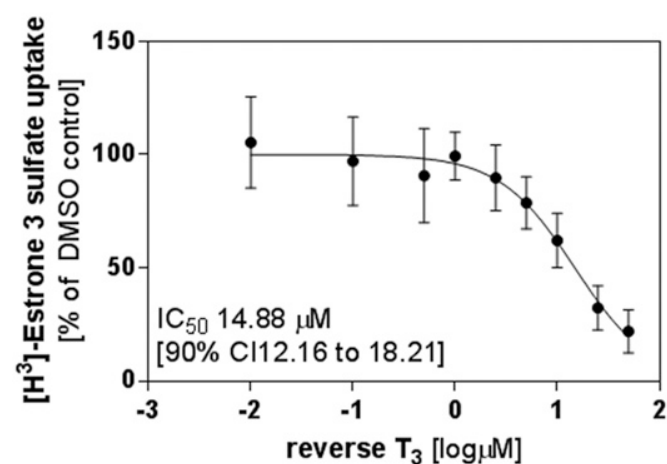

C

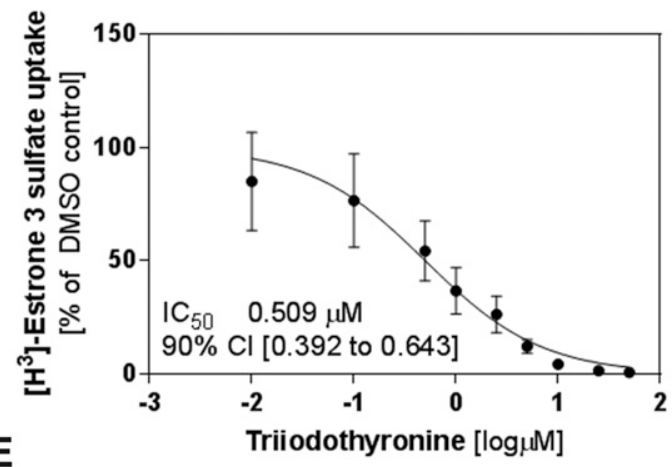

E

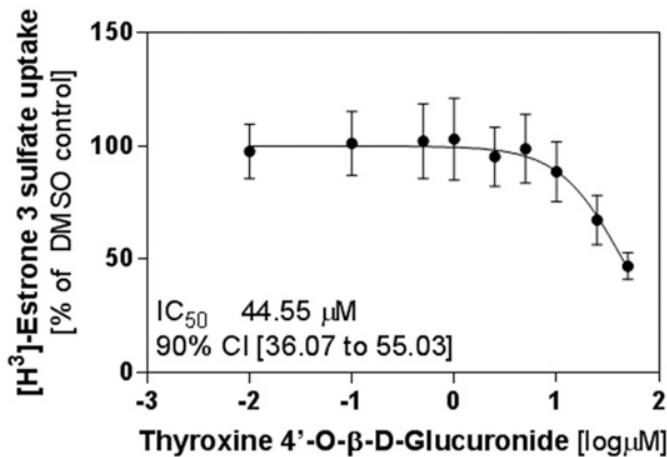

Fig. 2. Inhibition of OATP2B1-mediated uptake by $\mathrm{TH}$ derivatives. Uptake of $\left[{ }^{3} \mathrm{H}\right]-\mathrm{E}_{1} \mathrm{~S}$ in MDCKII-OATP2B1 was determined in the presence of different THs derived from $\mathrm{T}_{4}(\mathrm{~A})$. Cellular accumulation of $\mathrm{E}_{1} \mathrm{~S}$ was determined after incubation with increasing concentrations of $\mathrm{T}_{4},(\mathrm{~B}), \mathrm{T}_{3}(\mathrm{C}), \mathrm{rT}_{3}(\mathrm{D})$, or $\mathrm{T}_{4} \mathrm{G}(\mathrm{E})$. The logarithmic inhibitor response curves were fitted to determine the $\mathrm{IC}_{50}$ values and the respective confidence intervals $(\mathrm{CI})$. The data presented are of $n=3$ independent replicates each in triplicate.

In addition to the aforementioned injection solvent and eluents, the weak and strong wash solvents were water-ACN (50:50, v/v) containing $0.2 \%$ trifluoroacetic acid, and ACN-isopropanol-acetone (40:40:30, v/v/v) containing $0.2 \%$ trifluoroacetic acid, respectively. The seal wash solvent consisted of a water-ACN mixture (90:10, v/v). Multiple reaction monitoring detection was performed with electrospray ionization in positive ion mode. Nitrogen was used both as desolvation and nebulization gas. Argon was used as collision gas. The tandem mass spectrometry parameters were generated using IntelliStart software (Waters Corp.) followed by manual optimization. The optimized parameters are summarized in Table 1.

Statistical Analysis. Data are presented as mean \pm S.D. Data analysis was performed using GraphPad Prism software version 6.04 (GraphPad Software Inc., San Diego, CA) and Microsoft Excel (Microsoft, Redmond, WA). Values of $P \leq 0.05$ were considered as statistically significant.

\section{Results}

Influence of Thyroid Hormones on OATP2B1 Transport Activity. In a first approach, we tested the influence of
$\mathrm{T}_{4}$ and its metabolic products, namely $\mathrm{T}_{3}, \mathrm{rT}_{3}$, and $\mathrm{T}_{4} \mathrm{G}$ (Fig. 2A) on OATP2B1-mediated uptake of the known substrate $\mathrm{E}_{1} \mathrm{~S}$ using OATP2B1 expressing MDCKII cells. Expression of OATP2B1 (isoform 1B) in the cell model was verified by immunofluorescence microscopy (Fig. 1A) and western blot analysis (Fig. 1B) showing localization of OATP2B1 at the plasma membrane of overexpressing MDCKII-OATP2B1 cells. As shown in Fig. 2, B-E, all of the tested compounds significantly inhibited OATP2B1 transport function, thereby providing the first evidence of an interaction of THs with this membrane transporter. OATP2B1 function was potently inhibited by $\mathrm{T}_{4}\left(\mathrm{IC}_{50} 2.43 \mu \mathrm{M}\right.$, CI 2.91-3.08) and $\mathrm{T}_{3}\left(\mathrm{IC}_{50}\right.$ $0.51 \mu \mathrm{M}$ CI $0.39-0.64$ ), while rT3 ( $\mathrm{IC}_{50} 14.88 \mu \mathrm{M}$ CI $12.16-$ 18.21) and $\mathrm{T}_{4} \mathrm{G}\left(\mathrm{IC}_{50} 44.55 \mu \mathrm{M}\right.$ CI 36.07-55.03) exhibited lower inhibitory potency. Inhibition of OATP2B1 by the known OATP2B1 substrate, atorvastatin, served as a positive control of the experimental system (Fig. 1C). The influence of $\mathrm{TH}$ derivatives was also tested in Caco-2 cells transiently 


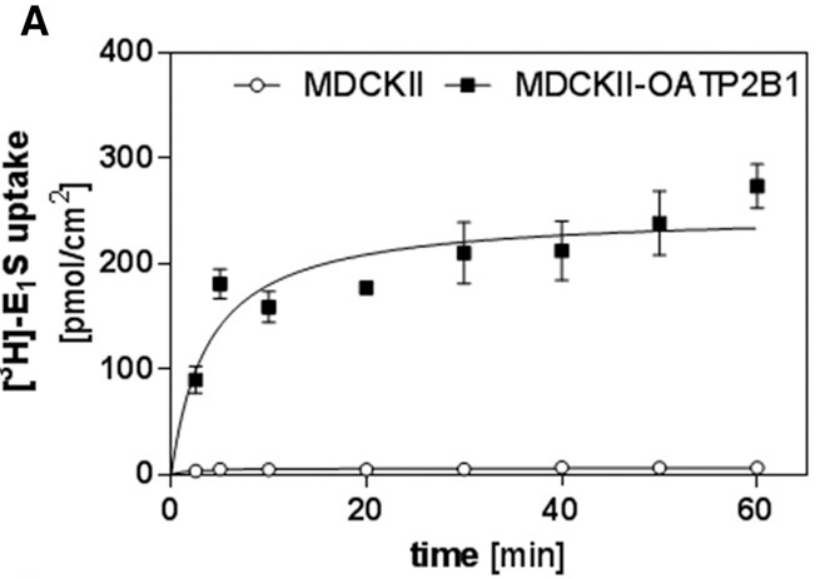

B

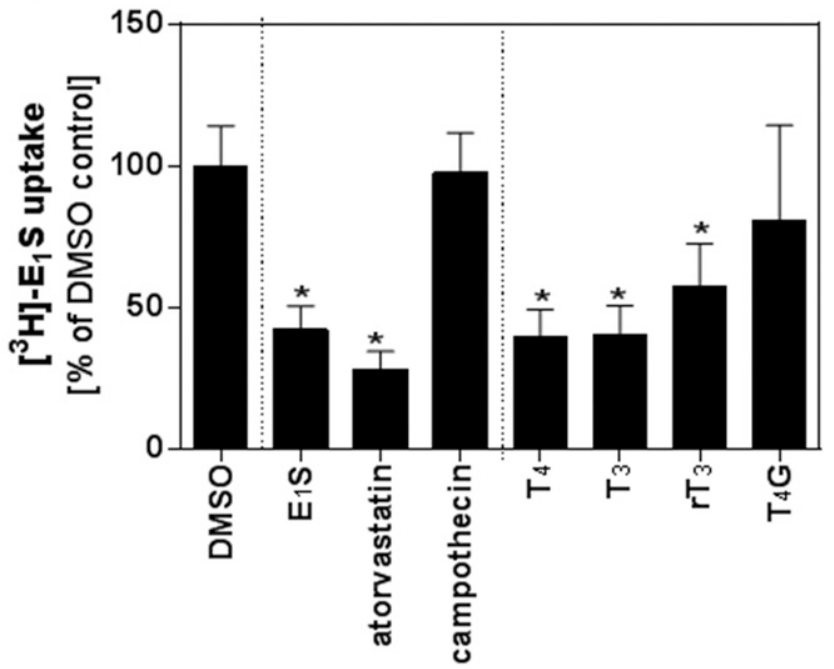

Fig. 3. Competitive counter-flow assays in MDCKII-OATP2B1 cells. Assessment of time-dependent accumulation of $\left[{ }^{3} \mathrm{H}\right]-\mathrm{E}_{1} \mathrm{~S}$ comparing MDCKII and MDCKII-OATP2B1 cells (A). Counter-flow experiments were conducted after reaching the steady state of $E_{1} S$ at 30 minutes of incubation. The cellular amount of the radiotracer was determined after 1 minute of incubation with $50 \mu \mathrm{M} \mathrm{E} \mathrm{E}_{1} \mathrm{~S}, 30 \mu \mathrm{M}$ atorvastatin, $1 \mathrm{mM}$ camptothecin, $25 \mu \mathrm{M} \mathrm{T}_{4}, 10 \mu \mathrm{M} \mathrm{T}_{3}, 1 \mathrm{mM} \mathrm{rT}_{3}$, or $400 \mu \mathrm{M} \mathrm{T}_{4} \mathrm{G}(\mathrm{B})$. The detected amount of radiotracer was normalized to that in cells treated with the solvent control. Data are presented as mean \pm S.D. $(n=3$ independent replicates each in triplicate). For the statistical analysis, one-way analysis of variance with Dunnett's multiple comparisons test was used $(* P \leq 0.05)$.

transfected with OATP2B1-pEF6 for overexpression of the transport protein. Using this cell model, we also observed inhibition of OATP2B1-mediated cellular accumulation of $\mathrm{E}_{1} \mathrm{~S}$ for $\mathrm{T}_{4}\left(\mathrm{IC}_{50} 4.81 \mu \mathrm{M}\right.$, CI 3.65-6.34), $\mathrm{T}_{3}\left(\mathrm{IC}_{50} 0.97 \mu \mathrm{M}\right.$ CI 0.611.53), $\mathrm{rT}_{3}\left(\mathrm{IC}_{50} 16.10 \mu \mathrm{M}\right.$ CI 11.44-22.65), and $\mathrm{T}_{4} \mathrm{G}$ (IC50 $57.21 \mu \mathrm{M}$ CI 38.11-85.89). Notably, the transport rate of $\mathrm{E}_{1} \mathrm{~S}$ in OATP2B1-transfected Caco-2 cells was lower than that observed for stably transfected MDCKII-OATP2B1 cells (mean transport rate \pm S.D.; fmol $\mu$ g protein ${ }^{-1} / \mathrm{min}^{-1}$; Caco2-OATP2B1 vs. MDCKII-OATP2B1; $0.268 \pm 0.055$ vs. $1.226 \pm$ $0.086 ; n=3$ independent replicates, each in biologic triplicate; $P<0.05$; ordinary one-way analysis of variance with Turkey's multiple comparisons test).

Competitive Counter-Flow Transport Studies with Thyroid Hormones in OATP2B1-Expressing Cells. Subsequently, competitive counter-flow experiments were conducted to determine whether the observed inhibition is due to transport of the tested TH derivative. Counter-flow was assessed in MDCKII-OATP2B1 cells at equilibrium, which was reached after 30 minutes of incubation with $\mathrm{E}_{1} \mathrm{~S}$ (compare Fig. 3A). An examination of the remaining amount of radiolabeled $\left[{ }^{3} \mathrm{H}\right]-\mathrm{E}_{1} \mathrm{~S}$ in cells exposed to $\mathrm{T}_{4}(25 \mu \mathrm{M}), \mathrm{T}_{3}(10 \mu \mathrm{M})$, and $\mathrm{rT}_{3}(1 \mathrm{mM})$ revealed significantly lower levels of the radiolabel compared with cells exposed to dimethylsulfoxide (DMSO) vehicle control (mean percentage of DMSO control \pm S.D.; $\mathrm{T}_{4}: 39.41 \% \pm 9.93 \%, \mathrm{~T}_{3}: 40.34 \% \pm 10.37 \% ; \mathrm{rT}_{3}: 57.20 \% \pm$ 15.37\%; one-way analysis of variance with Dunnett's multiple comparisons test; $P<0.05$ ), suggesting that these compounds are OATP2B1 substrates. In this assay, the known OATP2B1 substrates atorvastatin $(30 \mu \mathrm{M} ; 28.33 \% \pm 6.17 \%)$ and $\mathrm{E}_{1} \mathrm{~S}$ $(50 \mu \mathrm{M} ; 42.31 \% \pm 8.26 \%)$ expectedly reduced intracellular $\mathrm{E}_{1} \mathrm{~S}$ after addition in the steady state. Lastly, $\mathrm{T}_{4} \mathrm{G}(400 \mu \mathrm{M} ; 80.70 \% \pm$ $33.70 \%)$ and camptothecin $(97.71 \% \pm 14.07 \%)$ did not affect cellular $\mathrm{E}_{1} \mathrm{~S}$ equilibrium (Fig. $3 \mathrm{~B}$ ), indicating that these compounds were not substrates of OATP2B1.

Influence of OATP2B1 Transport Function on Intracellular Thyroid Hormone Effects. To provide additional evidence for OATP2B1 transport of THs, we tested the impact of OATP2B1 expression on intracellular TH signaling. MDCKII or MDCKII-OATP2B1 cells were used for cell-based reporter gene assays that examined transactivation of the human DIO1 promoter (see the illustration below the graphs in Fig. 4). With overexpression of the OATP2B1 transporter, transactivation of the DIO1 promoter was significantly enhanced by both $\mathrm{T}_{3}$ and $\mathrm{T}_{4}$ with cotransfection of $\mathrm{TR} \beta$ with or without RXR $\alpha$ (Fig. 4, A and B). Thyroid hormones did not activate the DIO1 promoter in both cell lines transfected with just RXR $\alpha$ (Fig. 4C); indicating the signal enhancement was $\mathrm{TR} \beta$ dependent. It is notable that the transfection efficacy in MDCKII was much lower than that of HepG2 or HeLa cells in cell-based reporter gene assays conducted in our laboratory. This, in part, explains the lower transactivation of the DIO1 promoter by about 3-fold, since we usually see a transactivation of about 5- to 6-fold compared with vector control in experiments with cells better accessible by transfection.

Expression of OATP2B1 and TR $\beta$ in Human Tissues and Cellular Models. Different tissues and commonly used cellular models of those organs were analyzed by real-time PCR to determine endogenous expression of the transporter OATP2B1 isoform 1B, OATP2B1 isoform 1E, TR $\beta$, TR $\alpha$, and DIO1. The DIO1 was only observed in liver kidney, and in Caco-2, HepG2, Huh-7, and RPTECs but not in LS180 cells (mean expression \pm S.D., relative to liver, Caco-2 vs. LS180 vs. Huh-7 vs. HepG2 vs. RPTEC, DIOI: $0.779 \pm 0.313$ vs. not detected vs. $0.038 \pm 0.003$ vs. $0.162 \pm 0.027$ vs. $0.006 \pm 0.006$, data not shown). As shown in Fig. 5, A and B, the mRNA of $\mathrm{TR} \alpha$ or $\mathrm{TR} \beta$ was observed in all tissues studied. Examination of the mRNA expression of the OATP2B1 isoforms verified the previous observation of isoform $1 \mathrm{~B}$ as enriched in the intestine, while isoform $1 \mathrm{E}$ (Fig. $5 \mathrm{E}$ ) was predominantly expressed in liver (Fig. 5F) (Knauer et al., 2013). For all genes examined in different cell models, the highest expression levels were observed in intestinal Caco-2 cells compared with LS180, Huh-7, HepG2, and RPTEC (mean expression \pm S.D., relative to liver, Caco-2 vs. LS180 vs. Huh-7 vs. HepG2 vs. RPTEC, TR $\alpha$ : $36.266 \pm 7.289$ vs. $28.116 \pm 6.395$ vs. $12.942 \pm$ 3.582 vs. $2.815 \pm 0.374$ vs. $7.531 \pm 1.686$; TR $\beta$ : $4.521 \pm 1.224$ vs. $4.321 \pm 0.372$ vs. $4.614 \pm 0.315$ vs. $1.022 \pm 0.162$ vs. $1.384 \pm$ 0.157 , OATP2B1-1B: $149.599 \pm 66.648$ vs. not detected vs. $14.071 \pm 4.627$ vs. $5.358 \pm 0.956$ vs. $0.145 \pm 0.074$ and 

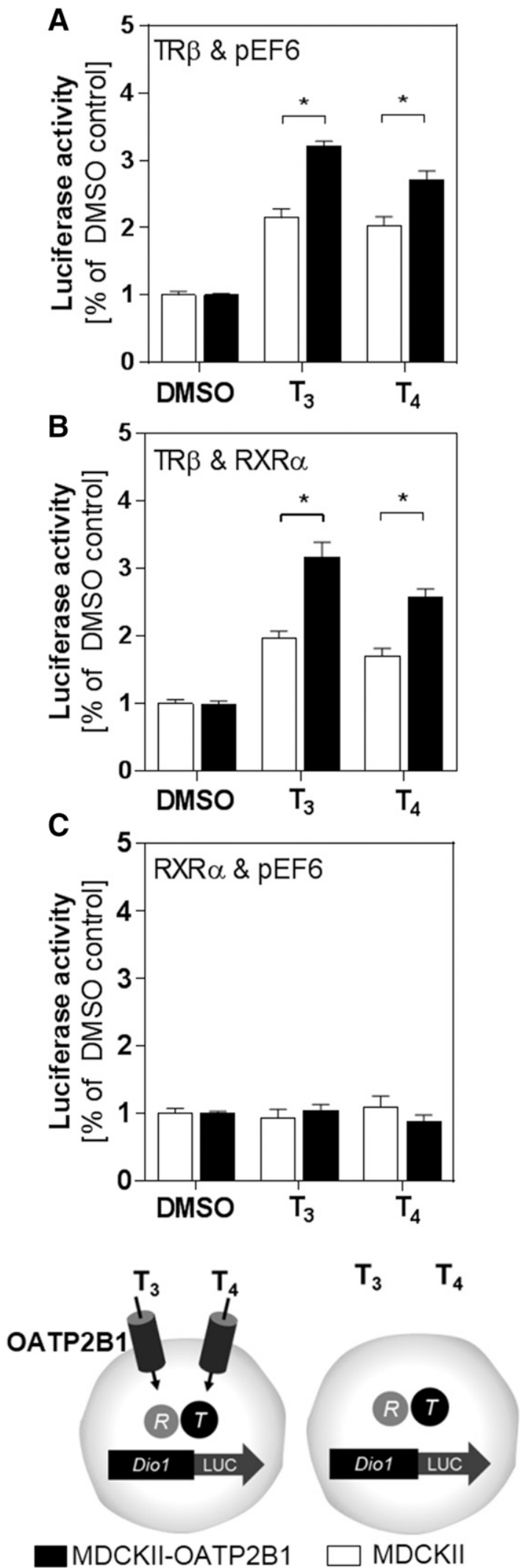

Fig. 4. Influence of OATP2B1 expression on transactivation of the DIO1 promoter. Transactivation of the DIO1 promoter was determined by cellbased dual luciferase assays comparing MDCKII with MDCKII-OATP2B1 cells (see the illustration below the graphs). Luciferase activity was assessed after treatment with $\mathrm{T}_{3}$ or $\mathrm{T}_{4}$. MDCKII or MDCKII-OATP2B1 cells were transfected with DIO1-pGL3basic and eukaryotic expression vectors encoding for $\mathrm{TR} \beta(\mathrm{A}), \operatorname{RXR} \alpha(\mathrm{B})$ or both (C). Data are presented as
OATP2B1-1E: $9.278 \pm 2.381$ vs. $3.553 \pm 0.334$ vs. $0.297 \pm 0.073$ vs. $0.222 \pm 0.083$ vs. $0.002 \pm 0.001$; Fig. $5, \mathrm{C}, \mathrm{D}, \mathrm{G}$, and $\mathrm{H}$ ), thereby supporting further use of Caco-2 cells for in vitro studies on the interactions of OATP2B1 and THs.

Quantification of Transcellular Transport of Thyroxine and Triiodothyronine in Caco-2 Cells. Transcellular flux of $\mathrm{T}_{4}$ or $\mathrm{T}_{3}$ was assessed in differentiated Caco- 2 cells cultured in Transwells. The amount of $\mathrm{T}_{4}$ and $\mathrm{T}_{3}$ in the apical or basal compartment was quantified by UHPLC-MS/MS. Solute flux studies in the A-to-B direction revealed that $\mathrm{T}_{4}$ exhibits intermediate permeability, while $\mathrm{T}_{3}$ shows low permeability since the $P_{\text {app }}$ value was below $3.3 \times 10^{-6} \mathrm{~cm} / \mathrm{s}$ $\left[\right.$ mean $P_{\text {app (A-B) }} \pm$ S.D. $(\mathrm{cm} / \mathrm{s}), \mathrm{T}_{4}: 3.70 \times 10^{-6} \pm 0.17 \times 10^{-6}$; $\mathrm{T}_{3}: 2.75 \times 10^{-6} \pm 7.08 \times 10^{-9}$ ]. Lower permeability was observed when examining transcellular transfer of THs in the B-to-A direction [mean $P_{\text {app (B-A) }} \pm$ S.D. $(\mathrm{cm} / \mathrm{s}), \mathrm{T}_{4}: 2.08 \times 10^{-6} \pm$ $\left.1.55 \times 10^{-9} ; \mathrm{T}_{3}: 0.893 \times 10^{-6} \pm 2.51 \times 10^{-9}\right]$. Similar results were obtained with $\mathrm{T}_{4}$ and $\mathrm{T}_{3}$ permeability after 60 minutes of incubation using the same system in the A-to-B direction [mean $P_{\text {app (A-B) }} \pm$ S.D. $(\mathrm{cm} / \mathrm{s}) ; \mathrm{T}_{4}: 2.75 \times 10^{-6} \pm 0.57 \times 10^{-6} ; \mathrm{T}_{3}: 3.36 \times$ $10^{-6} \pm 0.77 \times 10^{-6}$, data not shown] or B-to-A direction [mean $P_{\text {app (A-B) }} \pm$ S.D. $(\mathrm{cm} / \mathrm{s}) ; \mathrm{T}_{4}: 2.34 \times 10^{-6} \pm 0.32 \times 10^{-6} ; \mathrm{T}_{3}: 1.74 \times$ $10^{-6} \pm 0.36 \times 10^{-6}$ ]. However, calculating the uptake ratiowhich was conducted in a similar manner as the commonly used efflux ratio, but by dividing $P_{\text {app (A-B) }}$ by $P_{\text {app (B-A) }}$-revealed factors of $1.779 \pm 0.130$ and $3.203 \pm 0.909$ for $\mathrm{T}_{4}$ and $\mathrm{T}_{3}$, respectively; highlighting that there is a component in cellular transfer that enhances A-to-B flux, despite that low permeability observed. Addition of atorvastatin $(10 \mu \mathrm{M})$ as a known inhibitor of OATP2B1 in the bidirectional permeability assessment significantly changed the uptake ratios $\left(P_{\text {app (A-B) }} / P_{\text {app (B-A) }}\right)$ for $\mathrm{T}_{4}$ and $\mathrm{T}_{3}$ (Fig. 6). These results indicate the presence of atorvastatin-sensitive, TH transporters in Caco-2 cells.

Transcriptional Regulation of OATP2B1 by Thyroid Hormones. Furthermore, we examined whether $\mathrm{T}_{4}(100 \mathrm{nM})$ or $\mathrm{T}_{3}(100 \mathrm{nM})$ treatment influences the expression of OATP2B1 variants in Caco-2 or Huh-7 cells. Both OATP2B1 $1 \mathrm{~B}$ and $1 \mathrm{E}$ variants are expressed in Caco-2 and Huh-7 cells (Knauer et al., 2013). We found that $\mathrm{T}_{3}$ and $\mathrm{T}_{4}$ treatments increased the mRNA expression of the intestinal OATP2B1 1B variant by 10 -fold (mean \% of DMSO control \pm S.E.M., $1008 \% \pm$ $240 \%$ of control, $P<0.05$ ), and 4.8 -fold ( $480 \% \pm 140 \%$ of control, $P<0.05$ ), respectively, in Caco-2 cells (Fig. 7A). However, the THs did not appreciably increase the OATP2B1 1B mRNA expression in Huh-7 cells (Fig. 7D). The liver-enriched OATP2B1 1E variant mRNA expression was also induced 5.5fold $(549 \% \pm 118 \%$ of control, $P<0.05)$ by $\mathrm{T}_{3}$ and 2.7 -fold $(265 \%$ $\pm 69 \%$ of control, $P<0.05$ ) by $\mathrm{T}_{4}$ in Caco- 2 cells (Fig. $7 \mathrm{~B}$ ), but again not in Huh-7 cells (Fig. 7E). For controls, we examined the expression of DIO1 and ABCB1 (P-gp); two well-recognized TR target genes. As expected, both $\mathrm{T}_{3}$ and $\mathrm{T}_{4}$ treatments induced the expression of DIO1 in both Caco-2 (Fig. 7C) and Huh-7 cells (Fig. 7F). Induction was also observed for the expression of ABCB1 in Caco-2 (mean \% of DMSO control \pm S.D., $\mathrm{T}_{3}$ : $9100 \% \pm 8366 \% ; \mathrm{T}_{4}: 2054 \% \pm 507.8 \% ; n=5$, Kuskal-Wallis test, $P<0.05)$ and in Huh-7 cells $\left(\mathrm{T}_{3}: 148.2 \% \pm 52.6 \% ; \mathrm{T}_{4}\right.$ :

mean \pm S.D. ( $n=3$ independent replicates each in triplicate). For the statistical analysis, two-way analysis of variance with Sidak's multiple comparisons test was used $(* P \leq 0.05)$. 
A

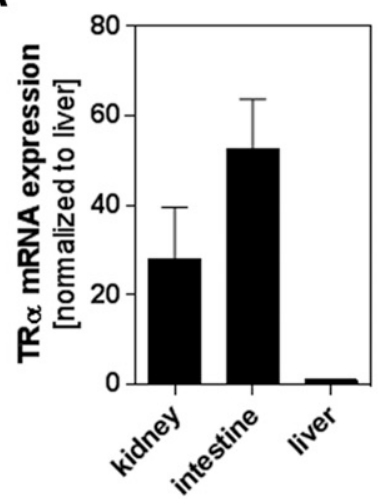

E

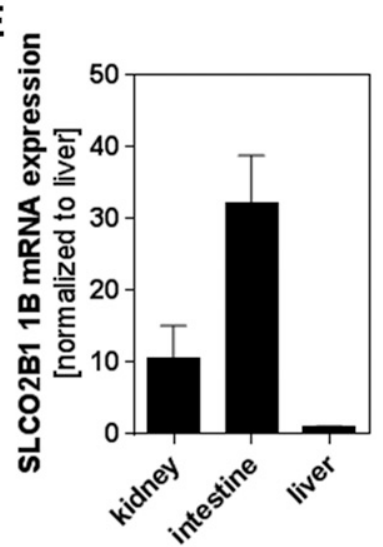

B

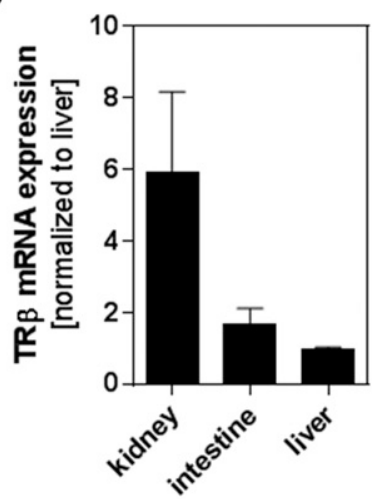

$\mathbf{F}$

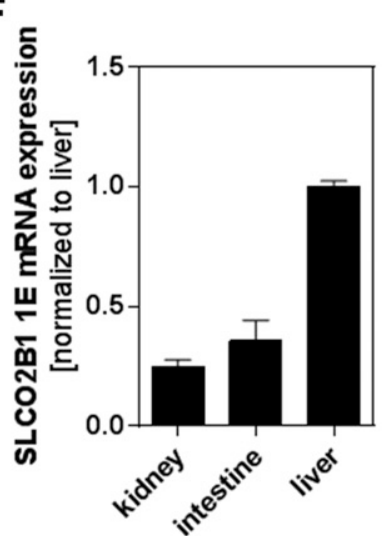

C

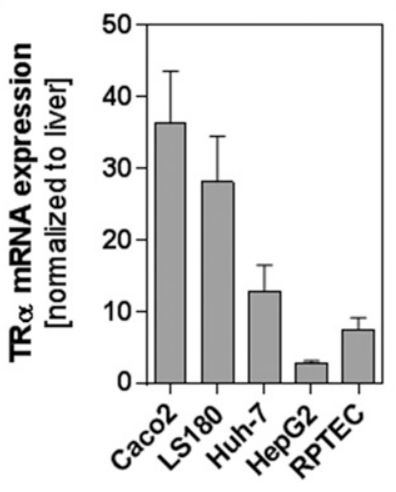

G

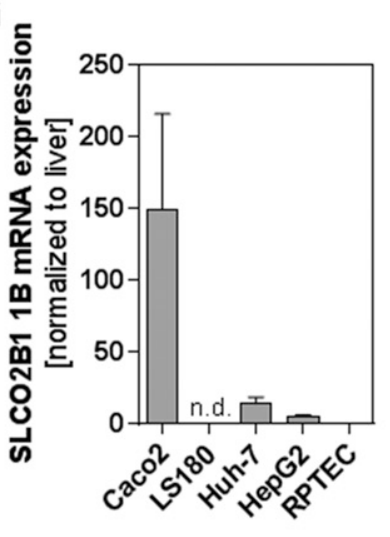

D

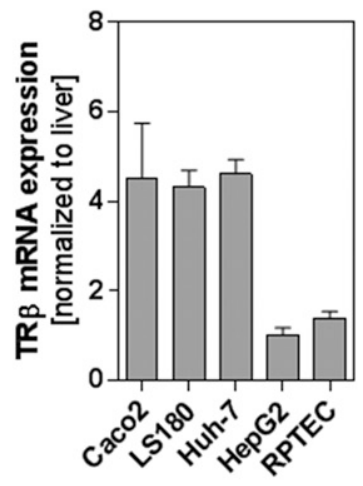

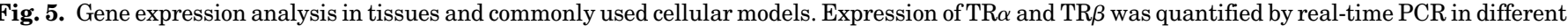

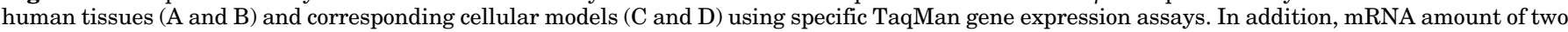

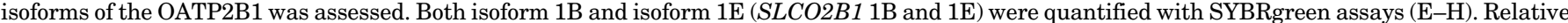

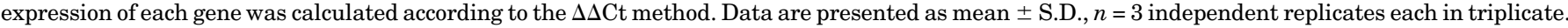

$161.1 \% \pm 63.87 \% ; n=5$, Kuskal-Wallis test, $P<0.05$ ) (data not shown). Similar results were observed when testing the influence of THs on OATP2B1 protein expression in differentiated Caco-2 cells cultivated for 14 days prior to $\mathrm{TH}$ exposure. As shown in Fig. 7, $\mathrm{G}$ and $\mathrm{H}$, expression of OATP2B1 was significantly increased by 2.6 -fold in the presence of $\mathrm{T}_{3}$ and by 2.9 -fold in the presence of $\mathrm{T}_{4}$. We additionally examined TH-mediated regulation of OATP2B1 expression in other intestinal and liver cell lines. With intestinal LS180 cells, there was significant increment in the OATP2B1 isoform 1E mRNA expression after exposure to $\mathrm{T}_{3}$ (mean expression \% of DMSO control \pm S.D.; DMSO vs. $\mathrm{T}_{3}$ vs. $\mathrm{T}_{4} ; 117.92 \pm 12.99$ vs. $294.07 \pm$ 41.46 vs. $244.36 \pm 156.71 ; n=3$ independent replicates each in triplicate; $P<0.05$; Kruskal-Wallis test with Dunn's multiple comparisons test). In LS180 cells, the amount of ABCB1 mRNA was also significantly increased by $\mathrm{T}_{3}$ treatment (DMSO vs. T3 vs. T4; $121.93 \pm 16.95$ vs. $1286.14 \pm 256.45$ vs. $738.32 \pm 400.22$; $P<0.05)$. However, for both genes we did not observe changes in expression after exposure of LS180 cells to $\mathrm{T}_{4}$. It is notable that the mRNA expressions of the OATP2B1 1B variant and that of DIO1 were not detected in LS180 cells. In HepG2 cells we tested the influence of $\mathrm{T}_{3}$ on $\mathrm{DIO} 1, \mathrm{ABCB} 1$, and the OATP2B1 variants, and observed no significant change in mRNA expression of any gene (mean expression \% of DMSO control \pm S.D.; DMSO vs. $\mathrm{T}_{3}$ DIO1: $105.01 \pm 2.81$ vs. $155.71 \pm 19.93$; ABCB1: $105.99 \pm 2.48$ vs. $89.96 \pm 15.25$; OATP2B1 1E: $103.81 \pm 1.64$ vs. $144.9 \pm 10.11$; OATP2B1 1B $104.81 \pm 2.22$ vs. $139.92 \pm 5.60 ; n=3$ independent replicates each in triplicate; $P>0.05 n=3$ independent replicates each in triplicate; Mann-Whitney test). Taken together, these results demonstrate that $\mathrm{THs}$ are positive regulators of OATP2B1 gene expression in a cell type-dependent manner.

OATP2B1 Promoter Analysis and Cell-Based Reporter Gene Assays. Transcriptional regulation by $\mathrm{THs}$ is mediated by TRs. These nuclear receptors bind to DNA response elements in the promoter region of their target genes. We performed an in silico analysis to search for the TR DNA-binding motifs DR4, ER6, and DR1 in the SLCO2B1 1b or $S L C O 2 B 1$ 1e promoters (Knauer et al., 2013). As summarized in Table 2 and shown in Fig. 8A, multiple potential response elements for TRs were identified in the sequences analyzed. In detail, the ER6 motif (AGTCCTcagtccAGGAAA) in positions -899 to -882 exhibited the highest rank in the analysis of the $S L C O 2 B 11 \mathrm{~b}$ promoter sequence, while the previously reported DR1 motif(AGGGCAaAGTCCA in positions -17 to -4 ), had the highest score in the $S L C O 2 B 1$ 1e promoter. Considering the differential tissue/cell expression of TR $\alpha$ and cell-type specific induction of OATP2B1 by THs, we examined whether the SLCO2B1 1b and SLCO2B1 1 e promoters were activated in the presence of $\mathrm{TR} \alpha$ and its activating ligand $\mathrm{T}_{3}$ in cell-based luciferase assays. The TR-sensitive DIO1 promoter served as the control in these experiments. We observed significantly enhanced luciferase activity after treatment with $\mathrm{T}_{3}$ in HeLa cells transfected with the $S L C O 2 B 11 \mathrm{~b}$ promoter (mean luciferase activity fold of pGL3b control \pm S.D.; DMSO vs. $\mathrm{T}_{3} ; 1.364 \pm 0.141$ vs. 
A

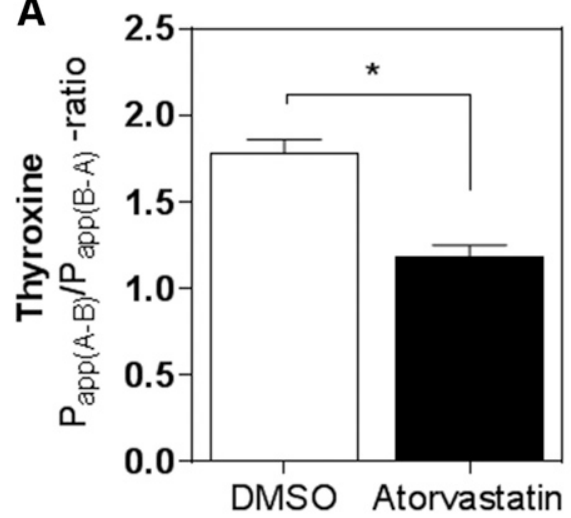

C

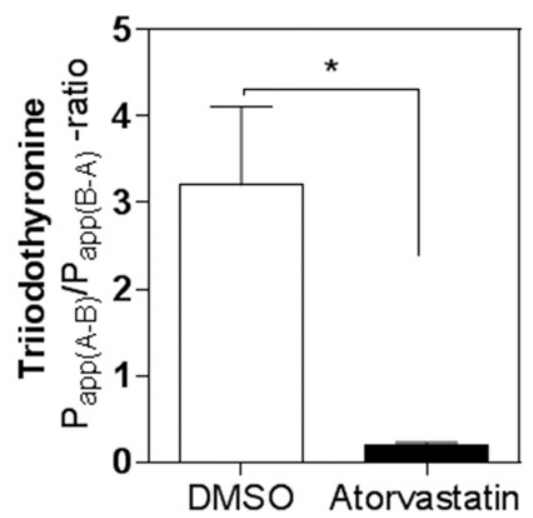

B

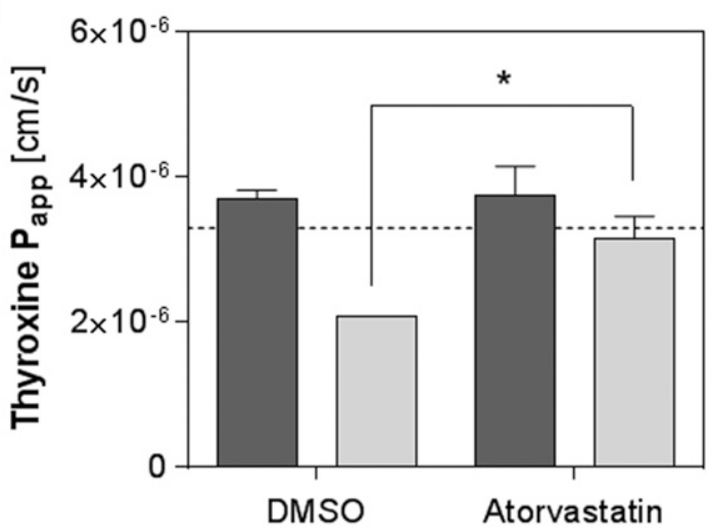

D

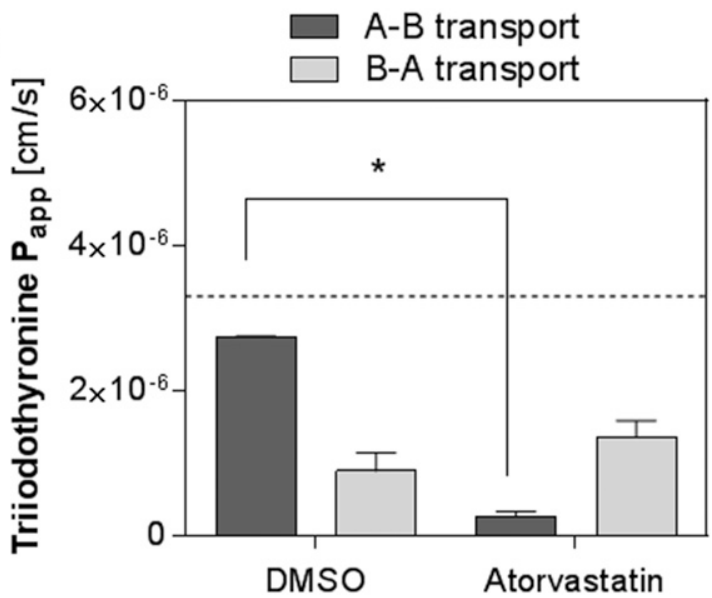

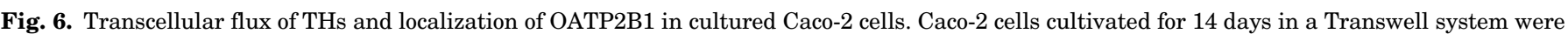

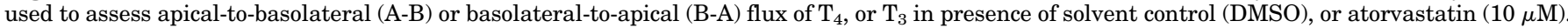

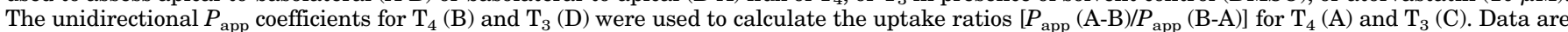
presented as mean \pm S.D. $(n=3$ independent replicates). For statistical analysis, Sidak's multiple comparisons test was used $(* P \leq 0.05)$.

$2.268 \pm 0.444 ; P<0.05$ student's $t$ test, Fig. 8B). Similarly, $\mathrm{T}_{3}$ treatment enhanced the $S L C O 2 B 1$ le promoter luciferase activity $(1.197 \pm 0.142$ vs. $2.260 \pm 0.485 ; P<0.05$ student's $t$ test, Fig. 8C). These results demonstrate that both SLCO2B1 $1 \mathrm{~b}$ and SLCO2B1 1e promoters are transactivated by TR $\alpha$.

\section{Discussion}

We report interaction of $\mathrm{THs}$ with the function and expression of OATP2B1. This ubiquitously expressed transporter, with suspected function in the intestinal absorption of drugs, was inhibited by all TH derivatives tested in OATP2B1-expressing cells. Furthermore, counter-flow experiments assessing the influence of $\mathrm{TH}$ derivatives on the cellular equilibrium of $\mathrm{E}_{1} \mathrm{~S}$ at steady state suggested that $\mathrm{T}_{3}, \mathrm{~T}_{4}$ and $\mathrm{rT}_{3}$ are not only inhibitors but also substrates of OATP2B1. This notion was further supported by findings showing that the presence of OATP2B1 significantly enhanced intracellular TH signaling as observed in cell-based reporter gene assays comparing MDCKII and MDCKIIOATP2B1 cells. The presence of an active transport component in the transcellular transport of $\mathrm{T}_{3}$ and $\mathrm{T}_{4}$ was supported by results of transcellular flux experiments in the intestinal cell line Caco-2. Indeed, we observed enhanced permeability in the A-to-B direction for both $\mathrm{T}_{4}$ and $\mathrm{T}_{3}$, resulting in uptake ratios $\left(P_{\text {app (A-B) }} / P_{\text {app (B-A) }}\right)$ of about 1.8 and about 3.2 for $\mathrm{T}_{4}$ and $\mathrm{T}_{3}$, respectively. Atorvastatin, which is a known substrate and competitive inhibitor of OATP2B1 (Grube et al., 2006), significantly reduced this ratio for $T_{3}$ and $T_{4}$. The observed reduction in the $\mathrm{TH}$ uptake ratio by atorvastatin could certainly be interpreted in terms of reduced uptake mediated by apically localized OATP2B1, but it should also be noted that multiple transporters are expressed in enterocytes and Caco-2 cells, of relevance being the efflux transporter ABCB1 (P-gp), which has previously been reported to also transport $\mathrm{T}_{3}$ (Mitchell et al., 2005). Moreover, atorvastatin is not a specific OATP2B1 inhibitor, and thus also interacts with several efflux transporters including the aforementioned ABCB1 (Chen et al., 2005). Despite that, we observed reduction in the net absorption of THs in the presence of atorvastatin in Caco- 2 cells, even if it is likely that there has been reduced apical TH efflux by ABCB1 in the presence of atorvastatin.

As previously mentioned, localization of OATP2B1 in enterocytes is a matter of an ongoing debate, which was sparked by recent experiments by Kaiser et al. (2017), indicating that OATP2B1 is localized in the basolateral membrane of enterocytes. This localization would be expected to result in an increase in the uptake ratio of OATP2B1 substrates in the presence of an inhibitor specific to this transporter, which has not been observed in the herein reported experiments. Even if we are not able to dissect the 
A

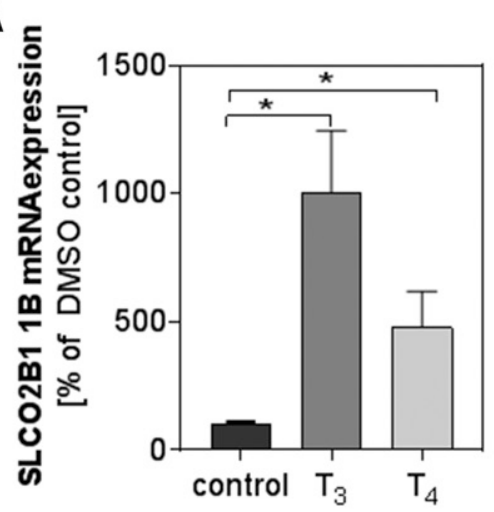

D

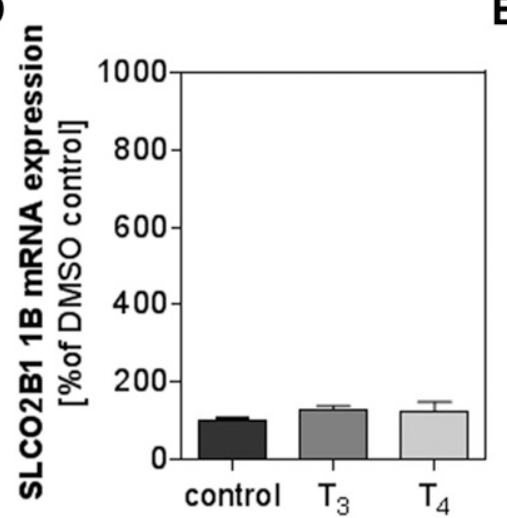

B

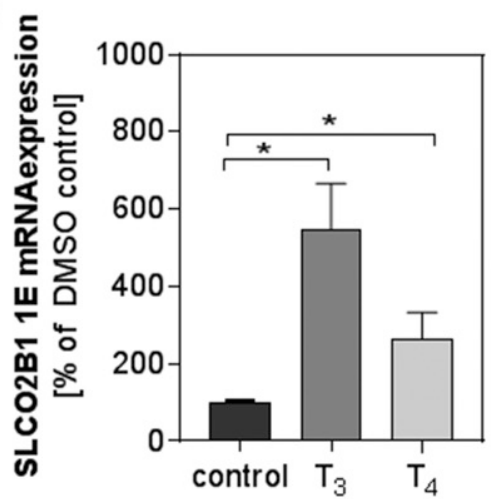

E

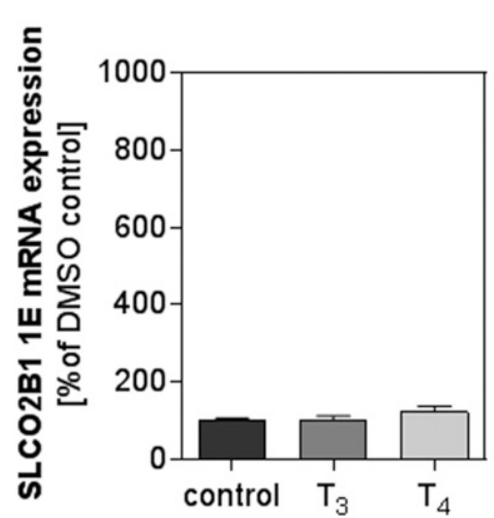

C

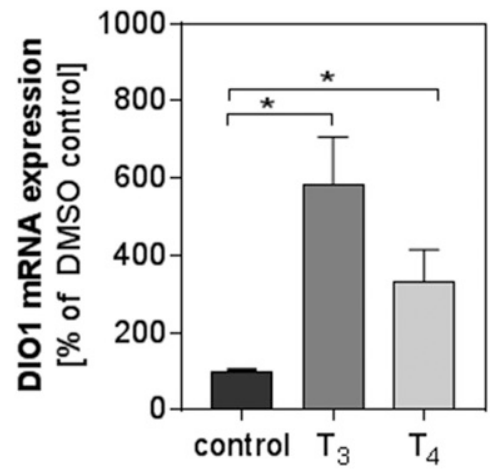

F

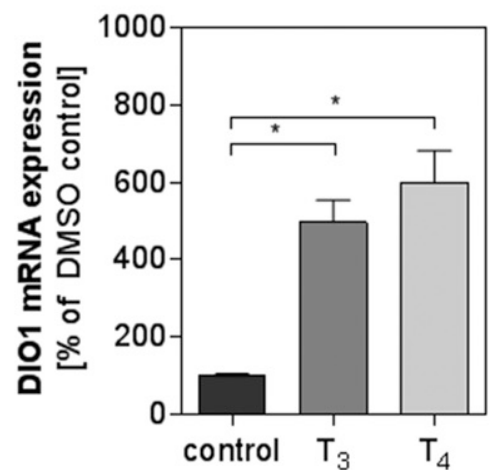

G

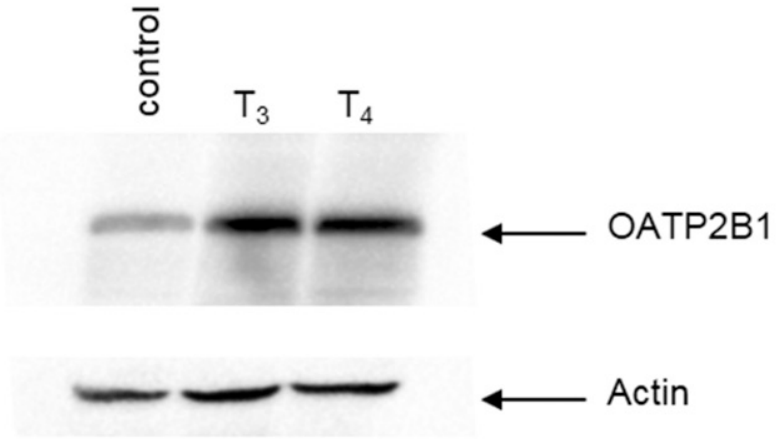

\section{H}

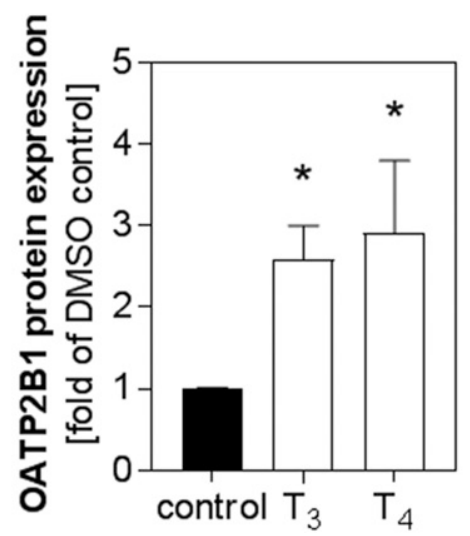

Fig. 7. Influence of THs on expression of OATP2B1. Expression of SLCO2B1 isoform 1B (A) SLCO2B1 isoform 1E (B) and deiodinase type 1 (C) mRNA was quantified by real-time PCR after 48 hours of treatment of differentiated Caco-2 cells with $\mathrm{T}_{3}(100 \mathrm{nM})$ or L-thyroxine ( $\left.\mathrm{T}_{4}, 100 \mathrm{nM}\right)$. Amount of $S L C O 2 B 1$ isoform 1B (D), SLCO2B1 isoform 1E (E), and deiodinase type 1 (F) mRNA was quantified by real-time PCR in Huh-7 cells treated with $\mathrm{T}_{3}$ $(100 \mathrm{nM})$ or $\mathrm{T}_{4}(100 \mathrm{nM})$. Expression data were calculated by the $\Delta \Delta$-Ct method, where expression was related to that of a housekeeping gene and then normalized to the solvent control. Data are presented as mean \pm S.E.M. of $n=5$ experiments. Gene expression was analyzed with a Kruskal-Wallis test with Dunn's multiple comparisons test. OATP2B1 protein expression was assessed by western blot analysis [representative result, (G)]. Actin served as the loading control $(\mathrm{H})$. Data obtained by densitometry of $n=3$ experiments are presented as mean \pm S.D., and comparisons were analyzed by one-way analysis of variance with Dunnett's multiple comparisons test $(\mathrm{E})(* P<0.05)$.

contribution of each Caco-2 transporter to $\mathrm{TH}$ fluxes since atorvastatin is a potent inhibitor of OATP2B1, but not specific for this transporter, our observation, which showed a reduction in the ratio, would be in agreement with findings by others showing expression of OATP2B1 in the apical membrane of enterocytes and Caco-2 cells (Tamai et al., 2001; Kobayashi et al., 2003).

Our data demonstrated inhibition of OATP2B1 function by $\mathrm{T}_{3}$ and $\mathrm{T}_{4}$ with in vitro $\mathrm{IC}_{50}$ values in the micromolar range.
Whether this inhibition is of clinical relevance with respect to $\mathrm{TH}$ being a perpetrator of pharmacokinetic drug interactions, especially in other tissues than intestine, is uncertain. However, normal $\mathrm{T}_{4}$ plasma concentrations range from 0.59 to $1.54 \mu \mathrm{M}$. Furthermore, $\mathrm{T}_{4}$ is significantly bound to serum proteins resulting in free $\mathrm{T}_{4}$ concentrations of $0.09-0.24 \mathrm{nM}$. Considering these low physiologic free plasma concentrations, it seems unlikely that $\mathrm{T}_{4}$ would alter the tissue distribution/ elimination of drugs through inhibition of OATP2B1. Similar 
TABLE 2

Summary of potential TR response elements in the SLCO2B1 $1 \mathrm{~b}$ and SLCO2B1 1e promoter region Analysis was performed using the publically available NUBIscan software. Response element marked with $\uparrow$ exhibited the highest score in the in silico analysis for this particular motif. Response element highlighted in bold had the highest score in the analysis of the respective promoter fragment. Response element marked with * was previously reported to be the most likely HNF $4 \alpha$ binding site, resulting in constitutive activity of the promoter in cells, where this transcription factor is present (Knauer et al., 2013).

\begin{tabular}{lcc}
\hline \multicolumn{1}{c}{ Motif } & Sequence & Position \\
\hline SLCO2B1-1b promoter & & \\
DR4-III & & -1756 to -1741 \\
DR4-II & GGGTCTgatcAGGTCA & -1078 to -1063 \\
ER6-II & AGGACAgagaAGCCAA & -1362 to -1345 \\
$\boldsymbol{E R 6 - I ^ { \dagger }}$ & TATCCTgggtggAGGGAA & $-\mathbf{8 9 9}$ to $-\mathbf{8 8 2}$ \\
DR4-I & AGTCCTcagtccAGGAAA & -405 to -390 \\
SLCO2B1-1e promoter & AGGCTGgaaaAGGACA & -2170 to -2186 \\
DR4-IV & & -2136 to -2149 \\
DR1-V & AGCACAtctgAGGCAA & -1241 to -1223 \\
ER6-I & AGAGCAaGGGCCA & -1222 to -1206 \\
DR4-III & TGACCTatttcaGGGTGA & -996 to 983 \\
DR1-IV & AGGTGGgagaAGGTCA & -954 to -941 \\
DR1-III & AGGTCTgAGGCCT & -167 to -155 \\
DR1-II & AGGACAgATCTCA & -55 to -40 \\
DR4-II & AGCCCAcAGGAAA & -46 to -30 \\
DR4-1 & AGGGAAgcacTGGCC & $-\mathbf{1 7}$ to $-\mathbf{4}$ \\
DR1- $\boldsymbol{I}^{* *}$ & TGGGCAggggAGGGAA & \\
\hline
\end{tabular}

considerations could be taken for $\mathrm{T}_{3}$, whose physiologic plasma total concentrations range from 0.01 to $0.03 \mu \mathrm{M}$.

At the clinical level, little is known regarding the role of OATP2B1 in the intestinal absorption of L-thyroxine. A clinical study was conducted by Lilja et al. (2005), motivated by a case in which a patient experienced significant changes in
L-thyroxine efficacy after grapefruit juice ingestion. Grapefruit juice is known to inhibit intestinal OATP2B1 (Satoh et al., 2005). The investigators found that grapefruit juice slightly reduced the L-thyroxine area under the plasma concentration-time curve by $9 \%$ within $0-6$ hours, which was concluded to be clinically insignificant. While this finding

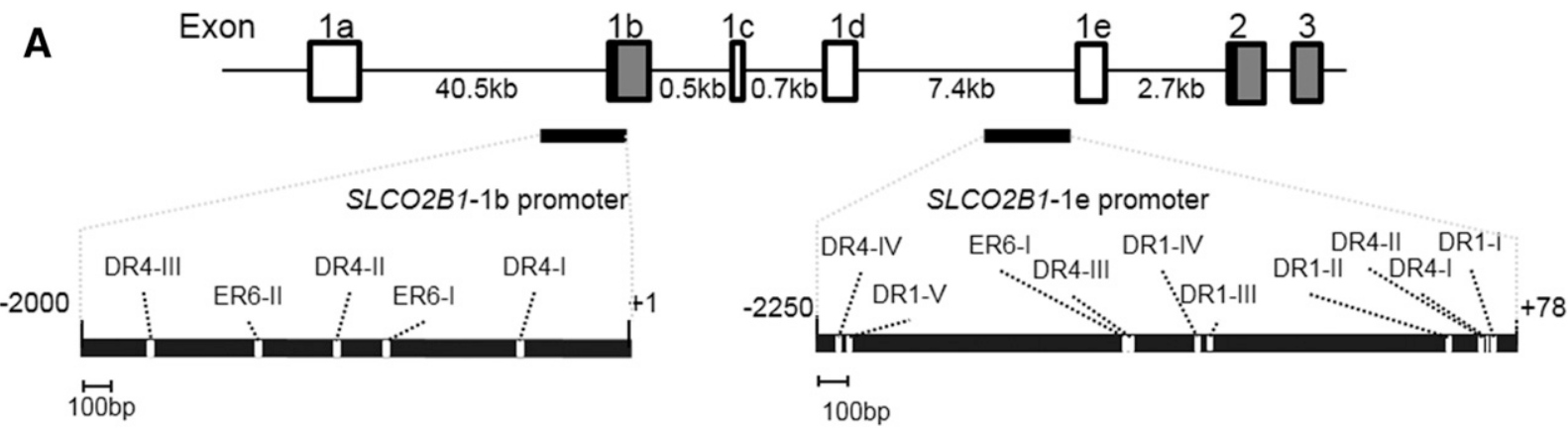

B

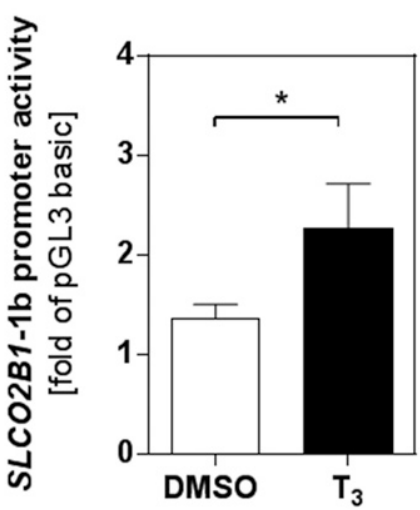

C

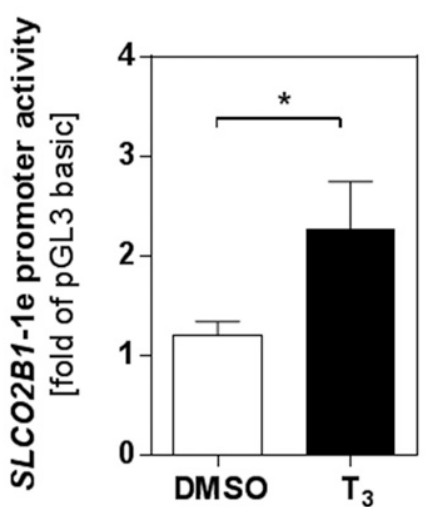

D

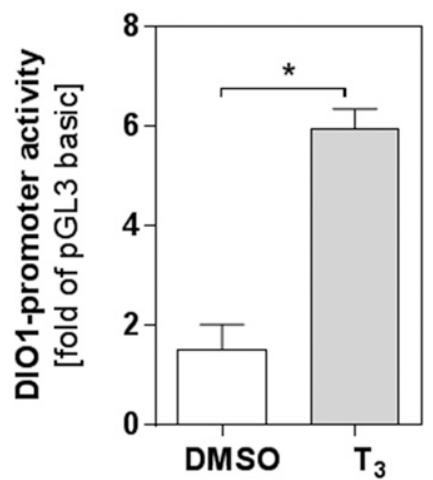

Fig. 8. TR $\alpha$-mediated transactivation of the SLCO2B1-1b or SLCO2B1-1e promoter. Arrangement of the respective region of the $S L C O 2 B 1$ gene locus depicting the different exons 1a to 1e. For the transcriptional start site variants SLCO2B1-1B and 1E, details on the localization of potential thyroid hormone receptor response elements in the respective promoter region are shown (A). Cell-based reporter gene assays were performed in HeLa cells transiently transfected with the SLCO2B1-1b (B), SLCO2B1-1e (C), or the Dio1 (D) promoter and treated with $\mathrm{T}_{3}(10 \mu \mathrm{M})$ or solvent control. Data are shown as the mean luciferase activity fold of pGL3-basic ( $n=3$ independent replicates each in triplicate); *, $<0.05$ Student's $t$ test. 
argues against the role of OATP2B1 in the oral absorption of L-thyroxine, it is notable that inhibition of OATP2B1 by grapefruit juice may be drug specific since the transporter possesses two binding sites for substrates and inhibitors (Shirasaka et al., 2012, 2014). Characterization of L-thyroxine binding to the high- and low-affinity binding sites and modulation by grapefruit juice remains to be determined. Another explanation for the lack of a significant pharmacokinetic interaction in the aforementioned study may be that it was conducted with healthy volunteers, while in the clinical case report the patient had hypothyroidism. The possibility that hypothyroidism may influence the magnitude of the juice/ L-thyroxine interaction is supported by our finding that OATP2B1 expression is regulated by THs.

We showed upregulation of OATP2B1 mRNA and protein expression in Caco- 2 cells by $\mathrm{THs}$, suggesting that $\mathrm{TH}$ status influences the expression and activity of the intestinal uptake transporter. A similar transcriptional regulation was observed when assessed in LS180 cells, an additional intestinal cell model previously used to show induction of ABCB1 after exposure to THs (Mitin et al., 2004). Interestingly, when examined in Huh-7 and HepG2 cells, models for hepatocytes, THs did not affect OATP2B1 expression, pointing to cell model-specific regulation. Expression of TR $\beta$ was observed in all cell models used in our study, suggesting that differential expression of this receptor is not the reason underlying the cell-specific effect. In contrast, quantification of TR $\alpha$ revealed a lower amount of this nuclear receptor in hepatic cell models, suggesting that this nuclear receptor may be involved in the regulation of OATP2B1 expression observed in the intestinal cells. Two N-terminal protein variants of OATP2B1 (variants $1 \mathrm{~B}$ and $1 \mathrm{E}$ ) have been described; these variants are assumed to be transcriptionally regulated by different promoter regions since their transcriptional start sites differ. In accordance are findings showing that the liver-enriched $S L C O 2 B 11 \mathrm{E}$, but not the ubiquitously expressed $S L C O 2 B 11 \mathrm{~B}$ transcriptional start site variant, is regulated by the transcription factor $\mathrm{HNF} 4 \alpha$ (Knauer et al., 2013). However, with respect to regulation by TR $\alpha$ we observed significant transactivation of both $S L C O 2 B 1$ promoters. Considering that multiple potential binding sites for TRs were predicted in the promoter sequences of SLCO2B1$1 \mathrm{~b}$ and $S L C O 2 B 1-1 \mathrm{e}$ and that TR $\alpha$ is the predominant nuclear receptor in intestine (Sirakov and Plateroti, 2011), differences in TR $\alpha$ expression levels may be the mechanism underlying the observed differences in transcriptional regulation in hepatic (Huh-7 and HepG2) and intestinal (Caco2 and LS180) cells.

There is evidence that $\mathrm{TH}$ status modulates expression and function of other drug transporters in the intestinal wall. For example, the efflux transporter ABCB1 that limits intestinal drug absorption is regulated by THs (Mitin et al., 2004). Indeed, the required doses of the ABCB1 substrate digoxin used to treat cardiac failure and to control heart rate differ among patients suffering from hyper- or hypothyroidism compared with patients with normal thyroid function. Specifically, higher and lower digoxin maintenance doses are needed with hyperthyroidism and hypothyroidism, respectively (Burk et al., 2010). It is notable that digoxin is not a substrate of OATP2B1 (Taub et al., 2011). Another study by Jin et al. (2005) showed that the trough plasma concentrations of the ABCB1 substrate cyclosporin A were lower in patients taking L-thyroxine. Increased expression of $\mathrm{abcb} 1 \mathrm{a} / \mathrm{abcb} 1 \mathrm{~b}$ in mice after long-term treatment with L-thyroxine was found to explain this clinical drug-drug interaction. Lastly, Siegmund et al. (2002) reported induction of intestinal ABCB1 in humans treated with L-thyroxine. However, this induction of $\mathrm{ABCB} 1$ resulted only in minor, nonclinically relevant changes in the pharmacokinetics of talinolol, an ABCB1 substrate (Siegmund et al., 2002). It is interesting that talinolol is also a substrate of the uptake transporters OATP2B1 and OATP1A2 (Shirasaka et al., 2010), despite that it is not anionic. It is possible that TH-mediated upregulation of the intestinal efflux mechanisms could be counteracted by the concomitant upregulation of OATP2B1, leading to minimal pharmacokinetic consequences for talinolol.

In conclusion, we report that $\mathrm{T}_{3}$ and $\mathrm{T}_{4}$ are substrates of OATP2B1, indicating a novel mechanism for regulation of $\mathrm{TH}$ homeostasis by influencing hormone distribution and absorption during replacement therapy. In addition, we showed upregulation of OATP2B1 by THs, which may be of relevance for intestinal absorption of substrate drugs with narrow therapeutic index.

\section{Acknowledgments}

We thank Janine Hussner for support during manuscript preparation.

\section{Authorship Contributions}

Participated in research design: Meyer zu Schwabedissen, Ferreira, Schaefer, Oufir, Tirona.

Conducted experiments: Meyer zu Schwabedissen, Ferreira, Schaefer, Oufir, Seibert, Tirona.

Contributed new reagents or analytic tools: Meyer zu Schwabedissen, Hamburger, Tirona.

Performed data analysis: Meyer zu Schwabedissen, Ferreira, Schaefer, Oufir, Tirona.

Wrote or contributed to the writing of the manuscript: Meyer zu Schwabedissen, Ferreira, Schaefer, Oufir, Hamburger, Tirona.

\section{References}

Ayers S, Switnicki MP, Angajala A, Lammel J, Arumanayagam AS, and Webb P (2014) Genome-wide binding patterns of thyroid hormone receptor beta. PLoS One 9:e81186.

Bernal J, Guadaño-Ferraz A, and Morte B (2015) Thyroid hormone transportersfunctions and clinical implications. Nat Rev Endocrinol 11:690.

Burk O, Brenner SS, Hofmann U, Tegude H, Igel S, Schwab M, Eichelbaum M, and Alscher MD (2010) The impact of thyroid disease on the regulation, expression, and function of ABCB1 (MDR1/P glycoprotein) and consequences for the disposition of digoxin. Clin Pharmacol Ther 88:685-694.

Centanni M, Gargano L, Canettieri G, Viceconti N, Franchi A, Delle Fave G, and Annibale B (2006) Thyroxine in goiter, Helicobacter pylori infection, and chronic gastritis. N Engl J Med 354:1787-1795.

Chen C, Mireles RJ, Campbell SD, Lin J, Mills JB, Xu JJ, and Smolarek TA (2005) Differential interaction of 3-hydroxy-3-methylglutaryl-coa reductase inhibitors with ABCB1, ABCC2, and OATP1B1. Drug Metab Dispos 33:537-546.

Drozdzik M, Gröer C, Penski J, Lapczuk J, Ostrowski M, Lai Y, Prasad B, Unadkat JD, Siegmund W, and Oswald S (2014) Protein abundance of clinically relevant multidrug transporters along the entire length of the human intestine. Mol Pharm 11:3547-3555.

Fujiwara K, Adachi H, Nishio T, Unno M, Tokui T, Okabe M, Onogawa T, Suzuki T, Asano N, Tanemoto M, et al. (2001) Identification of thyroid hormone transporters in humans: different molecules are involved in a tissue-specific manner. Endocrinology 142:2005-2012.

Garmendia Madariaga A, Santos Palacios S, Guillén-Grima F, and Galofré JC (2014) The incidence and prevalence of thyroid dysfunction in Europe: a meta-analysis. $J$ Clin Endocrinol Metab 99:923-931.

Glaeser H, Bailey DG, Dresser GK, Gregor JC, Schwarz UI, McGrath JS, Jolicoeur E, Lee W, Leake BF, Tirona RG, et al. (2007) Intestinal drug transporter expression and the impact of grapefruit juice in humans. Clin Pharmacol Ther 81:362-370.

Goldberg AS, Tirona RG, Asher LJ, Kim RB, and Van Uum SH (2013) Ciprofloxacin and rifampin have opposite effects on levothyroxine absorption. Thyroid 23: 1374-1378.

Grube M, Köck K, Oswald S, Draber K, Meissner K, Eckel L, Böhm M, Felix SB, Vogelgesang S, Jedlitschky G, et al. (2006) Organic anion transporting polypeptide $2 \mathrm{~B} 1$ is a high-affinity transporter for atorvastatin and is expressed in the human heart. Clin Pharmacol Ther 80:607-620. 
Harper JN and Wright SH (2013) Multiple mechanisms of ligand interaction with the human organic cation transporter, OCT2. Am J Physiol Renal Physiol 304 F56-F67.

Hollowell JG, Staehling NW, Flanders WD, Hannon WH, Gunter EW, Spencer CA, and Braverman LE (2002) Serum TSH, $\mathrm{T}_{4}$, and thyroid antibodies in the United States population (1988 to 1994): National Health and Nutrition Examination Survey (NHANES III). J Clin Endocrinol Metab 87:489-499.

Hubatsch I, Ragnarsson EG, and Artursson P (2007) Determination of drug permeability and prediction of drug absorption in Caco-2 monolayers. Nat Protoc 2 2111-2119.

Ianiro G, Mangiola F, Di Rienzo TA, Bibbò S, Franceschi F, Greco AV, and Gasbarrini A (2014) Levothyroxine absorption in health and disease, and new therapeutic perspectives. Eur Rev Med Pharmacol Sci 18:451-456.

Irving SA, Vadiveloo T, and Leese GP (2015) Drugs that interact with levothyroxine: an observational study from the Thyroid Epidemiology, Audit and Research Study (TEARS). Clin Endocrinol (Oxf) 82:136-141.

Jin M, Shimada T, Shintani M, Yokogawa K, Nomura M, and Miyamoto K (2005) Long-term levothyroxine treatment decreases the oral bioavailability of cyclosporin A by inducing P-glycoprotein in small intestine. Drug Metab Pharmacokinet 20: $324-330$

Keiser M, Kaltheuner L, Wildberg C, Müller J, Grube M, Partecke LI, Heidecke CD, and Oswald S (2017) The organic anion-transporting peptide 2B1 is localized in the basolateral membrane of the human jejunum and caco-2 monolayers. J Pharm Sci 106:2657-2663.

Knauer MJ, Girdwood AJ, Kim RB, and Tirona RG (2013) Transport function and transcriptional regulation of a liver-enriched human organic anion transporting polypeptide 2B1 transcriptional start site variant. Mol Pharmacol 83 1218-1228.

Kobayashi D, Nozawa T, Imai K, Nezu J, Tsuji A, and Tamai I (2003) Involvement of human organic anion transporting polypeptide OATP-B (SLC21A9) in pH-dependent transport across intestinal apical membrane. J Pharmacol Exp Ther 306:703-708.

Koenen A, Kroemer HK, Grube M, and Meyer zu Schwabedissen HE (2011) Current understanding of hepatic and intestinal OATP-mediated drug-drug interactions. Expert Rev Clin Pharmacol 4:729-742.

Köhrle J (2007) Thyroid hormone transporters in health and disease: advances in thyroid hormone deiodination. Best Pract Res Clin Endocrinol Metab 21:173-191.

Kullak-Ublick GA, Ismair MG, Stieger B, Landmann L, Huber R, Pizzagalli F, Fattinger K, Meier PJ, and Hagenbuch B (2001) Organic anion-transporting polypeptide B (OATP-B) and its functional comparison with three other OATPs of human liver. Gastroenterology 120:525-533.

Lee W, Glaeser H, Smith LH, Roberts RL, Moeckel GW, Gervasini G, Leake BF, and Kim RB (2005) Polymorphisms in human organic anion-transporting polypeptide 1A2 (OATP1A2): implications for altered drug disposition and central nervous system drug entry. J Biol Chem 280:9610-9617.

Leuthold S, Hagenbuch B, Mohebbi N, Wagner CA, Meier PJ, and Stieger B (2009) Mechanisms of $\mathrm{pH}$-gradient driven transport mediated by organic anion polypeptide transporters. Am J Physiol Cell Physiol 296:C570-C582.

Lilja JJ, Laitinen K, and Neuvonen PJ (2005) Effects of grapefruit juice on the absorption of levothyroxine. Br J Clin Pharmacol 60:337-341.

Mitchell AM, Tom M, and Mortimer RH (2005) Thyroid hormone export from cells: contribution of P-glycoprotein. J Endocrinol 185:93-98.

Mitin T, Von Moltke LL, Court MH, and Greenblatt DJ (2004) Levothyroxine up-regulates P-glycoprotein independent of the pregnane X receptor. Drug Metab Dispos 32:779-782.

Mondal S, Raja K, Schweizer U, and Mugesh G (2016) Chemistry and biology in the biosynthesis and action of thyroid hormones. Angew Chem Int Ed Engl 55: $7606-7630$.

Pizzagalli F, Hagenbuch B, Stieger B, Klenk U, Folkers G, and Meier PJ (2002) Identification of a novel human organic anion transporting polypeptide as a high affinity thyroxine transporter. Mol Endocrinol 16:2283-2296.
Podvinec M, Kaufmann MR, Handschin C, and Meyer UA (2002) NUBIScan, an in silico approach for prediction of nuclear receptor response elements. $\mathrm{Mol}$ Endocrinol 16:1269-1279.

Pomari E, Nardi A, Fiore C, Celeghin A, Colombo L, and Dalla Valle L (2009) Transcriptional control of human organic anion transporting polypeptide $2 \mathrm{~B} 1$ gene. $J$ Steroid Biochem Mol Biol 115:146-152.

Riley RJ, Foley SA, Barton P, Soars MG, and Williamson B (2016) Hepatic drug transporters: the journey so far. Expert Opin Drug Metab Toxicol 12:201-216.

Satoh H, Yamashita F, Tsujimoto M, Murakami H, Koyabu N, Ohtani H, and Sawada $\mathrm{Y}$ (2005) Citrus juices inhibit the function of human organic anion-transporting polypeptide OATP-B. Drug Metab Dispos 33:518-523.

Shirasaka Y, Kuraoka E, Spahn-Langguth H, Nakanishi T, Langguth P, and Tamai I (2010) Species difference in the effect of grapefruit juice on intestinal absorption of talinolol between human and rat. J Pharmacol Exp Ther 332:181-189.

Shirasaka Y, Mori T, Murata Y, Nakanishi T, and Tamai I (2014) Substrate- and dose-dependent drug interactions with grapefruit juice caused by multiple binding sites on OATP2B1. Pharm Res 31:2035-2043.

Shirasaka Y, Mori T, Shichiri M, Nakanishi T, and Tamai I (2012) Functional pleiotropy of organic anion transporting polypeptide OATP2B1 due to multiple binding sites. Drug Metab Pharmacokinet 27:360-364.

Siegmund W, Altmannsberger S, Paneitz A, Hecker U, Zschiesche M, Franke G, Meng W, Warzok R, Schroeder E, Sperker B, et al. (2002) Effect of levothyroxine administration on intestinal P-glycoprotein expression: consequences for drug disposition. Clin Pharmacol Ther 72:256-264.

Sirakov M and Plateroti M (2011) The thyroid hormones and their nuclear receptors in the gut: from developmental biology to cancer. Biochim Biophys Acta 1812:938-946.

Sugiyama D, Kusuhara H, Taniguchi H, Ishikawa S, Nozaki Y, Aburatani H, and Sugiyama Y (2003) Functional characterization of rat brain-specific organic anion transporter (Oatp14) at the blood-brain barrier: high affinity transporter for thyroxine. J Biol Chem 278:43489-43495

Tamai I, Nezu J, Uchino H, Sai Y, Oku A, Shimane M, and Tsuji A (2000) Molecular identification and characterization of novel members of the human organic anion transporter (OATP) family. Biochem Biophys Res Commun 273:251-260.

Tamai I, Nozawa T, Koshida M, Nezu J, Sai Y, and Tsuji A (2001) Functional characterization of human organic anion transporting polypeptide B (OATP-B) in comparison with liver-specific OATP-C. Pharm Res 18:1262-1269.

Taub ME, Mease K, Sane RS, Watson CA, Chen L, Ellens H, Hirakawa B, Reyner EL, Jani M, and Lee CA (2011) Digoxin is not a substrate for organic aniontransporting polypeptide transporters OATP1A2, OATP1B1, OATP1B3, and OATP2B1 but is a substrate for a sodium-dependent transporter expressed in HEK293 cells. Drug Metab Dispos 39:2093-2102.

van der Deure WM, Friesema EC, de Jong FJ, de Rijke YB, de Jong FH, Uitterlinden AG, Breteler MM, Peeters RP, and Visser TJ (2008) Organic anion transporter 1B1: an important factor in hepatic thyroid hormone and estrogen transport and metabolism. Endocrinology 149:4695-4701.

van der Deure WM, Peeters RP, and Visser TJ (2010) Molecular aspects of thyroid hormone transporters, including MCT8, MCT10, and OATPs, and the effects of genetic variation in these transporters. $J$ Mol Endocrinol 44:1-11.

Visser WE, Friesema EC, and Visser TJ (2011) Minireview: thyroid hormone transporters: the knowns and the unknowns. Mol Endocrinol 25:1-14.

Address correspondence to: Dr. Henriette E. Meyer zu Schwabedissen, Biopharmacy, Department of Pharmaceutical Sciences, University of Basel, Klingelbergstrasse 50,4056 Basel, Switzerland. E-mail: h.meyerzuschwabedissen@ unibas.ch or Dr. Rommel G. Tirona, Clinical Pharmacy, University of Toronto, 144 College Street, Toronto, ON M5S 3M2, Canada. Email: rommel.tirona@schulich. uwo.ca 